\title{
Denial, oblivion and new fears: Poliomyelitis and the post-polio syndrome in the Spanish and Portuguese press (1995-2009)
}

\author{
Juan Antonio Rodríguez-Sánchez and Inês Guerra-Santos
}

\section{Introduction: Learning to Forget Polio}

I n 1988 the World Health Assembly approved and launched the Global Polio Eradication Initiative, in which the governments of the member countries took part, as well as UNICEF, the US Centres for Disease Control and Prevention, the Rotary International and even the WHO, then followed by other organisations such as the United Nations Foundation, the World Bank and the Bill and Melinda Gates Foundation. This ambitious project not only had a strong scientific support regarding their viability, as well it was socially based on the success in eradicating smallpox, officially registered in 1980. The first results were obtained in the Region of the Americas, where the eradication certificate was achieved in 1994. ${ }^{1}$ The European Region, the third to achieve it, would have to wait until 2002.

The initial optimism, sometimes close to a disproportionate triumphalism, led to the setting of a date for the worldwide eradication of poliomyelitis in the year of 2000, which was then moved to 2005 and further continuously postponed, although with setting a specific year. The situation in 2009 was not encouraging, with cases of polio in 23 countries, some of them countries in which polio had been considered eradicated. The following year would not be better, because although the number of cases decreased and there were only cases in 20 countries, $88.53 \%$ of the cases were in countries where polio was not considered endemic. In this scenario, the WHO launched its Strategic Plan 2010-2012 (OMS, 2010). However, continued attempts to achieve the objectives had been frustrated by repeated

1 Nascimento, Dilene Raimundo do, Marcos Cueto, Eduardo Ponce Maranhão and Deepak Sobti, "A erradicação da poliomielite na América Latina: comparando Brasil e Peru,", pp. 161-176, in Dilene Raimundo de Nascimento, org., A história da poliomielite, Rio de Janeiro, 2010. 
expansions and new outbreaks of the virus in countries believed polio-free, to the point that the European Centre for Disease Prevention and Control considered, at the end of 2013, the risk of reintroduction of wild poliovirus in Europe from Syria and Israel. ${ }^{2}$ In return, on March $27^{\text {th }}$ of this year of 2014, the eradication has been certified in the South-East Asia.

The countries of the Iberian Peninsula, Portugal and Spain, declared the last cases of poliomyelitis produced by wild poliovirus in 1987 and 1989 respectively. However, this apparent parallelism occurred only on these final dates, as both endemism and vaccination had different models and results. Despite the high morbidity rate in both countries in the years of 1958 and 1959, the campaigns of mass oral vaccination did not arrive in Spain until 1963 and in 1965 in Portugal, after faint attempts of vaccination campaigns with the Salk vaccine, but locally, low impact on public health and some advertising revenue and justification of health policies in both dictatorships. ${ }^{3}$ The free oral mass vaccination campaigns were a huge success, which is demonstrated by the epidemiological statistics (Fig. 1).

In Portugal the connection of this campaign with the beginning of the Programa Nacional de Vacinação (National Vaccination Program) allowed a better control of the vaccinations, which did not happen in Spain until 1975, year of the introduction of the Calendario Vacunal (Vaccination Schedule). ${ }^{4}$ Since 1966, the morbidity rates in Portugal did not surpass 0.1 (with the exception of the outbreak which took place in Madeira, in 1972) and since 1974 they were even lower, with 1977 as the first year with no case of polio registered. Spain, nevertheless, had, due to the referred reasons, higher morbidity rates than Portugal and the surrounding countries throughout the period and only managed to achieve an effective

2 European Centre for Disease Prevention and Control. "Risk of introduction and transmission of wild-type poliovirus in EU/EEA countries following events in Israel and Syria updated risk assessment (9 december 2013). In http://ecdc.europa.eu/en/publications/ layouts/forms/Publication DispForm.aspx?List=4f55ad51-4aed-4d32-b960-

af70113dbb90\&ID=983 [15-01-2014]

3 Rodríguez-Sánchez, Juan Antonio and Jesús Seco Calvo, "Las campañas de vacunación contra la poliomielitis en España en 1963," Asclepio 61(1) (2009), 81-116; Guerra Santos, Inês, “A poliomielite em Portugal: o 'Refúgio da Paralisia Infantil'," pp. 177-194 in Dilene Raimundo de Nascimento, org., A história da poliomielite, Rio de Janeiro, 2010; Pinto, Sandrine Martins, Inês Guerra, Juan Antonio Rodríguez-Sánchez, João Rui Pita y Ana Leonor Pereira, "De las campañas de vacunación al calendario vacunal: el Programa Nacional de Vacinação portugués y las Campañas Nacionales de Vacunación Antipoliomielítica en España (1963-1976),”, pp. 203-209, in Ricardo Campos Marín, Ángel González de Pablo, María Isabel Porras Gallo y Luis Montiel, eds, Medicina y poder politico, Madrid, 2014.

4 Gil Prieto, Ruth, "Evolución de los calendarios vacunales en España," pp. 139-156 in Enrique Perdiguero Gil, Enrique and Josep M. Vidal Hernández, coords., Las vacunas: historia y actualidad, Menorca, 2008. 
Figure 1. Poliomyelitis morbidity in Spain and Portugal (1950-1976). Rate 0/0000

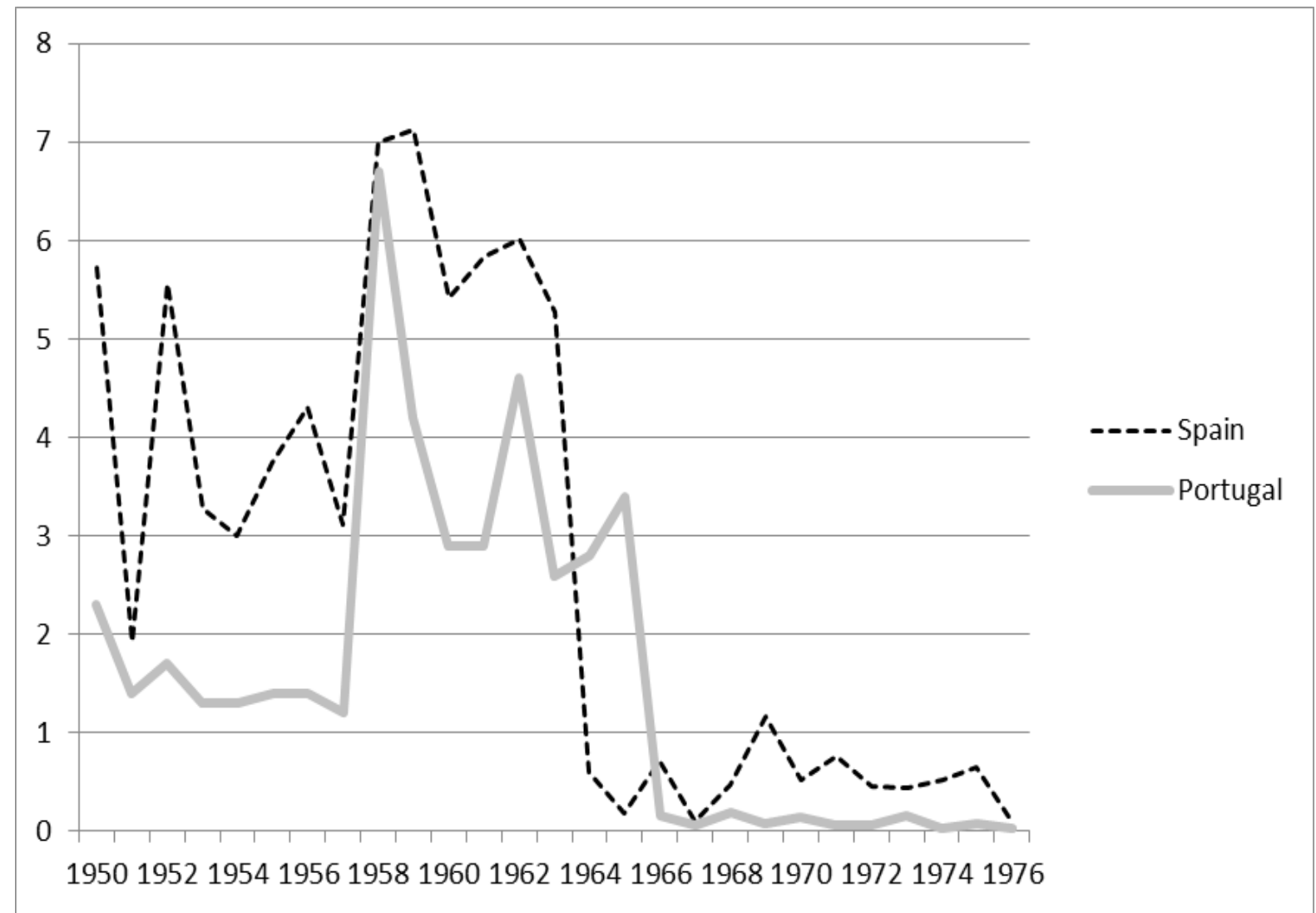

Source: Authors' own elaboration based on Revista de Sanidad, Anuário Estadístico and Boletim Epidemiológico.

reduction in the 80 s, when the new aid policies allowed reaching the whole children population. ${ }^{5}$

In Portugal, since 1979, there were only two cases of poliomyelitis, one in 1982 and, the last one, in 1987. In Spain it was not until 1989, that the cases of polio disappeared (Fig. 2).

This evolution of polio should be taken into account, for both the countries in the Iberian Peninsula and those in the whole of the European region and the world, to understand the social presence of its image and rapid forgetfulness, connected to the strong cultural imprint of a disease which affected younger children, leaving them with paralytic sequelae. Erase polio from the memory was a tacit strategy in the societies officially declared free of it, but little in accordance with the reality of those still living with the sequelae of polio, its late effects and even the appearance of the post-polio syndrome. Therefore, this work analyses the presence of polio in

5 Rodríguez-Sánchez, Juan Antonio, "Responsabilidades não assumidas: a poliomielite na Espanha (1954-1967)," pp. 195-224, in Dilene Raimundo de Nascimento, org., A história da poliomielite, Rio de Janeiro, 2010; Pinto et al, 2014. 
Figure 2. Poliomyelitis morbidity in Spain and Portugal (1976-1990). No of cases

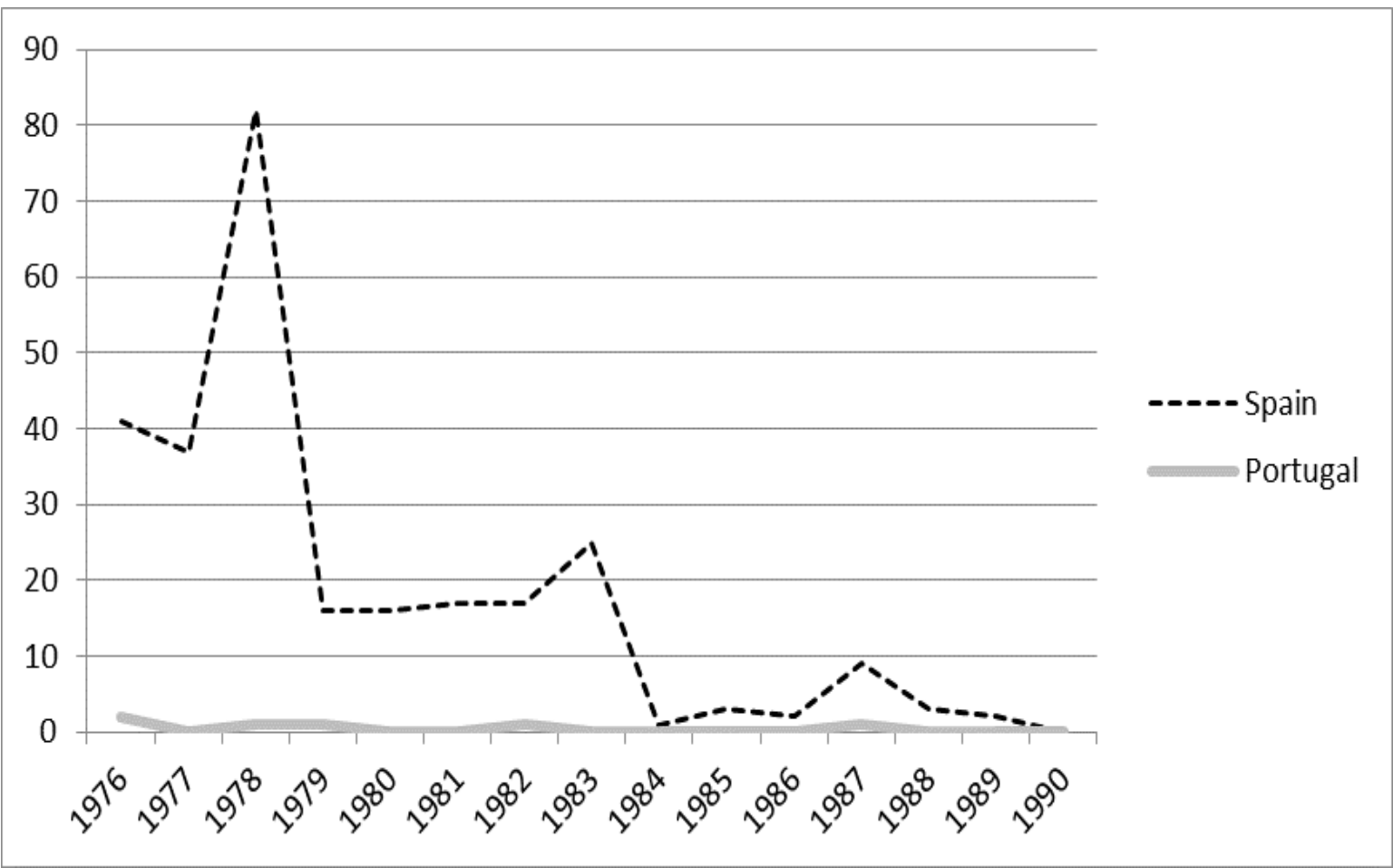

Source: Authors' own elaboration based on Revista de Sanidad, Anuário Estadístico and Boletim Epidemiológico.

the Spanish and Portuguese press in a period marked by the eradication and the absence of the disease. ${ }^{6}$ The temporal dimension is marked by both international events: the first successful results in the global eradication of the disease - with the award of the certificate in the Region of the Americas in 1994 - and the first public recognition of the difficulties in meeting the eradication goals (with the creation of the Strategic Plan for 2010 by the WHO) and the implied goals for oblivion, as in 2010 , the ICD finally recognised the post-polio syndrome as a nosological entity.

\section{The Media Construction of the End of Polio}

From a theoretical point of view it is considered that the news production corresponds to a social construction of reality in which social meanings are defined and redefined, formed and reformed. From this point of view and facing the objectives of this study, we have chosen to resort to the theories of agenda-setting and framing, two of the most representative contemporary theories of communication. Both developed from the seventies of the last century onward. The first one starts off with the studies of Maxwell McCombs, Bernard Cohen and

6 Smallman-Raynor, Mathew and Andrew D. Cliff, Poliomyelitis: Emergence to Eradication. Oxford, 2006, pp. 563-629. 
functionalist paradigm, while the second originates in the streams of cognitive psychology and the sociology of Goffman.

The basic assumption of the theory of the agenda is that the issues highlighted by the media determine what the audience thinks. In other words, we can consider that the fact that the media are selective about the topics to which they pay more or less attention determines the importance that the audience itself will grant them. This fact acquires more importance if we think that this selection not only has an impact on public opinion, but it can also justify (or not) certain political actions (third level of performance of the agenda of the media, as suggested by Rogers and Dearing, 1988).

In the same sense, the classical study by Lippman (1922) considers that the media determine the "cognitive maps of the world", given that they transfer and grant highlight to certain images or discourses on certain themes. ${ }^{8}$ It is a simple principle: the elements which are more often highlighted by the media gain more relevance and importance for the audience. However, this principle cannot be considered new: the content analysis proposed by Bardin presupposed that the number of times a word or a group of words is repeated has a direct connection with the importance granted to a certain theme. The differential aspect raised by the theory of agenda is that perception of the importance of a theme is transferred to the audience itself, thus conditioning its priorities agenda, that is to say that the priorities of the first become those of the latter. Obviously, it is important to highlight that, if there are subjects which are emphasized, there are also others which tend to be deferred and even ignored.

If the theory of the agenda tells us about its impact on the matters, the theory of framing takes a step further in considering that not only is what to think defined, but also the content of that thought. For Entman (1993, p. 52), framing would mean relating certain aspects of the perceived reality and turn them more relevant in the communicative text with the goal to promote a particular definition of a problem. ${ }^{9}$ Although both theories tend to be confused, we can interpret the second one as an extension of the first, stepping from the domain of attention or focalisation to a different dimension: that of interpretation, understanding and interiorising (which leads to the subjective plan of opinion). The framing assumes contextualisation, identification of attributes (often distorted from reality), patterns of selection, inclusion/exclusion and emphasis/relegation.

7 Rogers, E. and J. Dearing, "Agenda Setting research: where has it been, where is it going?," pp. 555-593, in J. Anderson, ed., Communication yearbook II, Newbury Park, CA, 1988.

8 McCombs, Maxwells, A Teoria da Agenda: a mídia e a opinião pública. Petrópolis, 2009.

9 Entman, R.M., "Framing: Toward clarification of a fractured paradigm," Journal of Communication 43(4) (1993), p 52. 
Entman (1991, p. 2) suggests that the new framing should be built on a basis of keywords, metaphors, symbols and images emphasized from the news, which ends up having an impact on the audience. ${ }^{10}$ Santos (2012) highlights that such influence surpasses the simple persuasion to imply alterations and variations in the relevance granted to a subject or another. The audience emerges then as a passive element. ${ }^{11}$

The impact of the media on the public opinion may be justified by a sort of need for guidance. On the one hand, the audience wishes for such guidance to serve as a basis for their own constructions of reality and, on the other, the media have an opportunity to demonstrate, reinforce and legitimise their action. It is then understood that McCombs (2006) suggests that the bigger the need for guidance by the individuals, the greater the possibility that they will pay attention to the agenda of the media and undertake it as theirs, with an impact that may affect their own behaviour. ${ }^{12}$ For this author, uncertainty would be another element to take into account, given that the increase of the degree of uncertainty is related to higher levels of the need for guidance. To this element we may add that of relevance: Severo (2007) relates this concept with that of uncertainty in the sense that a higher relevance tends to lead to a greater search for information to reduce that uncertainty and when it considerably diminishes, the audience resorts to the media only to follow possible changes in such an already known situation. ${ }^{13}$

One other element to be taken into account is the so called time-lag, the time interval which elapses between the media coverage by the media and the audience agenda, revealing the degree of importance attributed to the various themes.

Santos (2012) suggests that the agenda of the media is conditioned by a series of external factors, such as political pressure or the business strategies, which is also important to bear in mind. ${ }^{14}$

Finally, we must consider that the level of exposure to the media is decisive. The higher the individual's exposure to the media, the higher the probability that they will condition the thought; on the other, the larger the coverage / audience of the media, the larger its impact.

The resource to these theories as theoretical support implies a combination of quantitative and qualitative methodologies in order to identify, for example, which are the themes considered more relevant at a certain period of time and, simultaneously, which meaning is attributed to them.

10 Entman, R.M., "Framing U.S. coverage of international news: Contrast in narratives of the KAL and Iran air incidents," Journal of Communication 41(4) (1991), p 2.

11 Santos (2012) Santos, João de Almeida, Media e poder: O poder mediático e a erosão da democracia representativa. Lisboa, 2012.

12 McCombs, Maxwells, Estableciendo la agenda: El impacto de los medios en la opinión pública y en el conocimiento. Madrid, 2006.

13 Severo, Bruna Meireles, A Imprensa e seus efeitos sobre a audiência. Rio de Janeiro, 2007.

14 Santos, J.A, 2012. 
In this article we start from the assumption that the media, particularly the journalistic writing, stopped perceiving polio as a problem in the countries of the Iberian Peninsula, progressively linked polio to programs of international cooperation and development (ICD) in countries in Africa and Asia and thus built an image of a distant and foreign disease which was already part of the past, both in Portugal and Spain. This fact, led to the reduction of information about polio with the consequent neglect of it - and especially, and with worse consequences, about the post-polio syndrome. So being, polio and post-polio syndrome have been forgotten in the agenda of the media and, consequently, in that of the audience and even in the political agenda.

To this end we have analysed two newspapers in each country, of general information, paid, with a national scope, selected due to the fact that they are those with the largest circulation and readership in their respective countries and presented a broad ideological spectrum: El Pais (Prisa), El Mundo (Unidad Editorial, RCS Media Group), Jornal de Notícias (ControlInveste) and Público (Sonaecom). While the El País and the Público can be considered as having many common elements (not only their centre-left position, but also due to their membership in the World Media Network), the El Mundo is linked - through the Rizzoli group - to newspapers such as the Italian Il Corriere della Sera and its position is defined as liberal, close to the centre-right parties in Europe and very critical of the Partido Socialista Obrero Español (Spanish Socialist Workers Party). Also in the centre-right, more conservative than liberal, is the Jornal de Noticias, with a clear populist and regionalist trend. We must consider that in Portugal the diffusion rate of the written press was three times lower than the European average in the period of time analysed (and, together with Greece, the country of the European Union with less development of the daily press), although the audience (reading pervasiveness rate) was greater than the Spanish, which one needs to know to qualify the conclusions.

We conducted our research on their digitised printed editions (1995-2009), both to study a broad chronological period (15 years) and to explore the presence of polio not only as an article, but also in all references to it and the contexts in which they were produced, as the social impact of the disease has become part of a collective imaginary which grants it's with metaphorical uses and therefore associates it with hardly identifiable themes without resorting to automated digital search.

The problem met was the lack of digitisation of the Portuguese press for that period and also the hard and costly access to the one which was digitised. That motivated that, in the case of the Público, we only counted on the digital information as of the year of 2000, when its first graphical redesign occurred. The criteria for maintaining the daily Público as one of the objects of our research were due to the following considerations: the journalistic style, more reflexive, critical 
and rigorous, and because it is a newspaper which despite the fact that in its print edition is not the most read, it is the one with the largest number of subscriptions in its digital edition. Methodologically, given that the inclusion criteria used result from a definition imposed by external conditions, understandable and reasonable, it allows us to consider that the results achieved are valid, as they result from objective proceedings, based in the same analysis criteria.

This methodological validity is reinforced by the criterion of comprehensiveness which conducted the research and analysis. For the research we used truncations and logical operators, staring from the intersection of more specific terms to progressively incorporate others, wider, until the exclusive use of the truncation *polio*. Albeit the documentary noise increases, it also allows us to check the comprehensiveness. The results have been divided into "entries" (or items) which are those informative or publicity pieces where poliomyelitis is referred and "articles" which are those informative pieces where polio is the main theme (it is present in the title, subtitle or opening paragraph, photo captions or a main approach in the body of the article). The specific features of inclusion and exclusion have been determined.

The quantitative results are presented on table 1 and figures 3 and 4 .

Table 1. Entries and articles about polio and PPS in Spanish and Portuguese newspapers (1995-2009)

\begin{tabular}{cccccccccccccccccc}
\hline Year & \multicolumn{1}{c}{ Entries polio } & \multicolumn{1}{c}{ Art. polio } & \multicolumn{1}{c}{ Entries PPS } & \multicolumn{1}{c}{ Art. PPS } \\
\hline \multicolumn{1}{c}{} & EP & EM & JN & P & EP & EM & JN & P & EP & EM & JN & P & EP & EM & JN & P \\
\hline $\mathbf{1 9 9 5}$ & 35 & 23 & 0 & & 5 & 1 & 0 & & 0 & 0 & 0 & 0 & 0 & 0 & 0 & 0 \\
$\mathbf{1 9 9 6}$ & 34 & 33 & 0 & & 5 & 3 & 0 & & 0 & 0 & 0 & 0 & 0 & 0 & 0 & 0 \\
$\mathbf{1 9 9 7}$ & 26 & 29 & 2 & & 3 & 4 & 0 & & 0 & 1 & 0 & 0 & 0 & 1 & 0 & 0 \\
1998 & 23 & 21 & 2 & & 0 & 0 & 0 & & 1 & 1 & 0 & 0 & 0 & 0 & 0 & 0 \\
$\mathbf{1 9 9 9}$ & 33 & 35 & 0 & & 1 & 1 & 0 & & 1 & 0 & 0 & 0 & 0 & 0 & 0 & 0 \\
$\mathbf{2 0 0 0}$ & 30 & 43 & 5 & & 3 & 6 & 1 & & 2 & 2 & 0 & 0 & 1 & 0 & 0 & 0 \\
$\mathbf{2 0 0 1}$ & 25 & 20 & 4 & 6 & 2 & 5 & 0 & 1 & 0 & 0 & 0 & 0 & 0 & 0 & 0 & 0 \\
$\mathbf{2 0 0 2}$ & 25 & 17 & 8 & 5 & 8 & 6 & 3 & 3 & 3 & 0 & 0 & 0 & 0 & 0 & 0 & 0 \\
$\mathbf{2 0 0 3}$ & 26 & 29 & 3 & 12 & 4 & 2 & 0 & 3 & 0 & 0 & 0 & 0 & 0 & 0 & 0 & 0 \\
$\mathbf{2 0 0 4}$ & 22 & 29 & 7 & 18 & 8 & 7 & 2 & 4 & 1 & 1 & 0 & 0 & 1 & 0 & 0 & 0 \\
$\mathbf{2 0 0 5}$ & 27 & 42 & 8 & 25 & 6 & 6 & 2 & 6 & 1 & 0 & 0 & 0 & 1 & 0 & 0 & 0 \\
$\mathbf{2 0 0 6}$ & 35 & 32 & 2 & 18 & 4 & 2 & 0 & 2 & 1 & 0 & 0 & 0 & 0 & 0 & 0 & 0 \\
$\mathbf{2 0 0 7}$ & 21 & 35 & 4 & 10 & 2 & 2 & 1 & 2 & 1 & 0 & 1 & 0 & 0 & 0 & 0 & 0 \\
$\mathbf{2 0 0 8}$ & 21 & 20 & 5 & 11 & 1 & 1 & 0 & 1 & 1 & 0 & 0 & 0 & 0 & 0 & 0 & 0 \\
$\mathbf{2 0 0 9}$ & 14 & 18 & 17 & 11 & 2 & 5 & 1 & 0 & 2 & 2 & 0 & 0 & 1 & 0 & 0 & 0 \\
\hline TOTAL & 397 & 426 & $\mathbf{6 7}$ & $\mathbf{1 1 5}$ & $\mathbf{5 4}$ & $\mathbf{5 1}$ & $\mathbf{1 0}$ & $\mathbf{2 2}$ & $\mathbf{1 4}$ & $\mathbf{7}$ & $\mathbf{1}$ & $\mathbf{0}$ & $\mathbf{7}$ & $\mathbf{1}$ & $\mathbf{0}$ & $\mathbf{0}$ \\
\hline
\end{tabular}

Source: Authors' own elaboration. 
Figure 3. Entries about polio in Spanish and Portuguese newspapers (1995-2009)

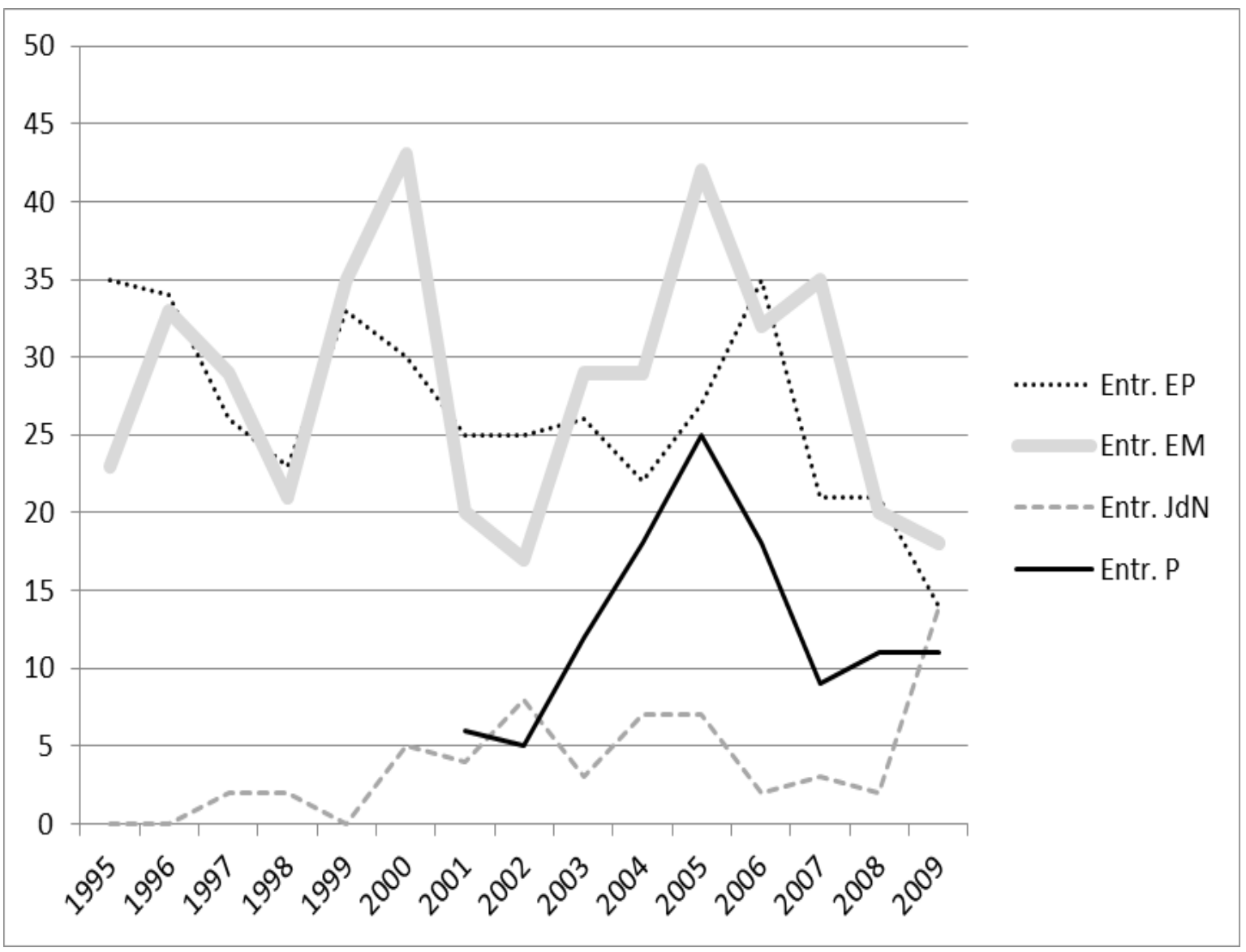

Source: Authors' own elaboration.

The various lines found between the entries or references found for Portugal and Spain (Fig. 3), especially in the case of the Jornal de Noticias, may also be attributable to the distinct precision in the information search and recovery system, normally resulting from the quality of the digitisation, given that the latter conditions the exactitude of the optical character recognition software (OCR). Notwithstanding, this consideration is only applicable to the entries with smaller characters (commercials, billboards, television), which are also those of lesser informative relevance and never to the articles.

The articles were subjected to a qualitative analysis (with the Atlas.ti software). The analysis was based on the grounded theory, initially free coding and later definition of hierarchies and creation of families of codes. From the results achieved, we have identified the main problems approached, which are those that structure the following presentation. 
Figure 4. Articles about polio in Spanish and Portuguese newspapers (1995-2009)

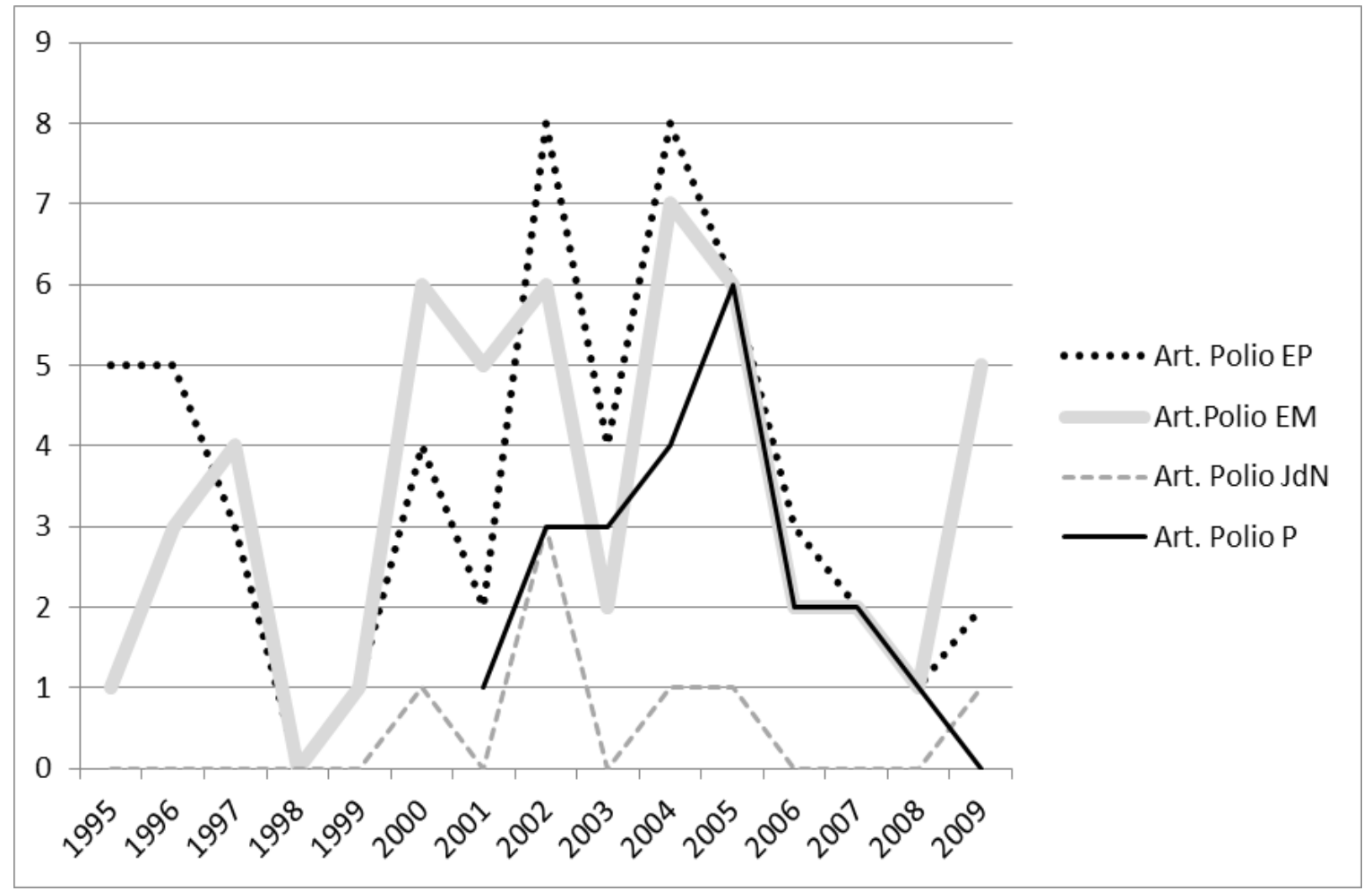

Source: Authors' own elaboration.

\section{A Disease Remote in Time and Space}

The last case of poliomyelitis occurred in Spain, in 1988. In Portugal the last case took place in 1987, after a decade in which only three cases had been reported. The reduced morbidity rates and years free of polio cases led to a quick forgetfulness of the disease and its sequelae. The newspapers did so recognise and, although the certificate of polio eradication in the European Region was only achieved in 2002, their agendas stopped including polio as an important information theme.

For the period analysed, polio is approached from two points of view conditioned by the alienation of the problem. Polio becomes a health problem in countries in Africa and Asia which requires intervention according to the premises of international cooperation; a problem which not only appeals to solidarity, but also to the awareness of the effects it could have on the polio-free West to a new expansion of the virus. Therefore, the goal of eradication feeds, in the pages of the press, from both solidarity and fear.

The second perspective is that of polio in some countries in which there is no memory of it; consequently its image will emerge associated with the past through the sequelae of those who suffered from it, even if they will just have informative relevance when the virus is associated with other diseases that do constitute a public health problem or are part of scientific researches with various implications. 
Therefore, we first analyse the information content referring to polio outside the Iberian Peninsula, and then we consider the issues about polio in Spain and Portugal which were object of attention for the press in the study period. The timing will be discussed later, as well as the issues that were not given informative relief.

\section{From Charity to Solidarity}

In the analysed period, the press builds a picture of poliomyelitis associated with poor countries and totally divorced from the reality of Portugal and Spain. The photographs accompanying the articles on vaccination campaigns are significant, whether or not they are photos of polio: the administration of oral vaccine becomes a symbol for vaccination and those who receive it are always children of readily identifiable ethnic groups (by race or clothes) and from other continents.

Polio is associated with poverty and ignorance, which, in the case of the Spanish press, has a more obvious approach in the El Pais: the descriptions of the remote areas where new outbreaks occur often present them as economically depressed and the most common obstacle to the success of vaccination campaigns would be the beliefs that would support the anti-vaccination. The difficulties for the eradication are mainly attributed to cultural reasons, although the role of armed conflicts is also highlighted. In the Spanish press, El Mundo will be the one which more explicitly expresses the economic cost of vaccination campaigns as one of the difficulties.

From this perspective, the countries affected by polio are portrayed as recipients of international cooperation actions for health, led by the WHO and UNICEF.

For the period under analysis, we can observe the movement of the forms of solidarity towards polio. Unlike Portugal, Spain had, since 1963, a specific association for people affected by polio. The date of creation indicates that this was an organization tolerated by the government of the Franco dictatorship and that it posed as a charity. For the period analysed, the ALPE (Asociación Española de Lucha contra la Poliomielitis - Spanish Association against Polio) maintained these typical charitable activities through the collection of donations through concerts or auctions, whose funds would go to people with polio sequelae. ${ }^{15}$ The advertisements for these activities are abundant in the early years analysed and until the year of 2000, when financial problems led to the seizure of their property. In Portugal, people with polio integrated themselves into broader associative movements for people with disability, which contributed to their invisibility.

It is precisely the turn of the millennium which will mark this significant change, when the beneficence of ALPE towards people with polio from "here" would be

15 Rodríguez-Sánchez, Juan Antonio, "Las secuelas sociales de la polio: los inicios del movimiento asociativo en España (1957-1975)," Dynamis 32(2) (2012b), 391-414. 
displaced by the demands of international organizations for cooperation in the eradication of polio in distant countries. The WHO and UNICEF thus became the organizations more strongly linked to polio in the press, which would be joined by the Rotary Club (and in particular, Rotary International), although the methods of fundraising remained similar: auctions and charity events, even though the latter would have the support of their television broadcasts.

In Portugal, the Jornal de Notícias maintained a connection between polio and charity, through a section of Catholic charity called "Every Man is your brother", where there were requests for monetary assistance for people with financial difficulties who needed wheelchairs and other devices. This type of discourse can be considered residual of that evident connection to Catholicism - charity / welfare disability which occurred in the countries of the Iberian Peninsula. ${ }^{16}$

The geographical distance between readers and disease is also reflected in the information about donors and Spanish researchers who will conduct their activity in countries with polio: Medicus Mundi, Intervida, Ayuda en Acción or missionaries from various religious congregations, present themselves as examples of international cooperation for the development, which include actions on polio.

In the case of Portugal, there would have to be the qualification of the special circumstance of proximity in time to the colonial era, which would justify the interest in polio in Angola (also discussed in the Spanish press, but less frequently), Mozambique, Cape Verde or Timor, close in time to its independence (1975), although geographically distant, which allowed to highlight the epidemiological break with the other links.

\section{The Danger is the other: Polio as a Metaphor}

The calls made by the media for solidarity to contribute financially to vaccination in countries with epidemics do not prevent these people from also being presented as an obstacle to the eradication and a constant danger due to the transmission of a virus that could return to the West.

Polio, in the newspaper articles analysed, is associated with terms like risk, danger or threat (Table 2 and fig. 5).

16 Rodríguez-Sánchez, 2012b; Rodríguez-Sánchez, Juan Antonio, Rosa Ballester Añón and Inês Guerra Santos, "El movimiento asociativo: una perspectiva internacional, nacional y de los casos de Madrid, Valencia y Castilla - La Mancha," pp. 233-257, in María Isabel Porras Gallo, Mariano AyarzaGüena Sanz, Jaime de las Heras Salord y María José Báguena Cervellera, coords., El drama de la polio: un problema social y familiar en la España franquista, Madrid, 2013. 
Figure 5. Articles about poliomyelitis and risk in Spanish and Portuguese newspapers (1995-2009). Rate 0/0

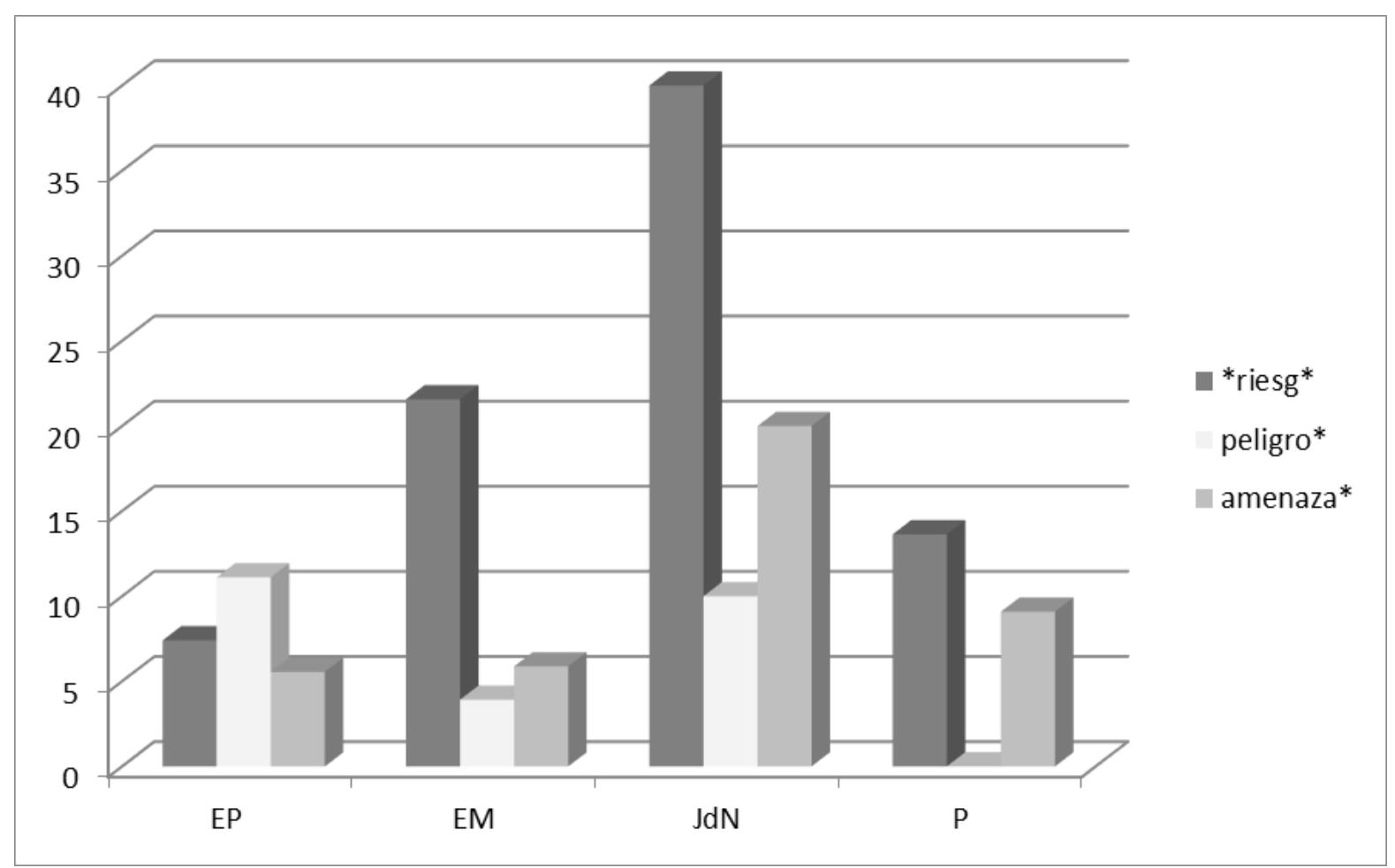

Source: Authors' own elaboration

Table 2. Articles about polio and risk (1995-2009)

\begin{tabular}{cccccccccccccccccc}
\hline Year & \multicolumn{3}{c}{ Entries polio } & \multicolumn{4}{c}{ Art. polio } & \multicolumn{1}{c}{ Entries \% } & \multicolumn{4}{c}{ Art. \% } \\
\hline & EP & EM & JN & P & EP & EM & JN & P & EP & EM & JN & P & EP & EM & JN & P \\
\hline${ }^{*}$ riesg* & 63 & 58 & 10 & 5 & 4 & 11 & 4 & 3 & 15,87 & 13,61 & 14,92 & 4,35 & 7,41 & 21,57 & 40 & 13,64 \\
peligro* $^{2}$ & 49 & 43 & 3 & 2 & 6 & 2 & 1 & 0 & 12,34 & 10,09 & 4,48 & 1,74 & 11,11 & 3,92 & 10 & 0 \\
amenaza $^{*}$ & 28 & 23 & 3 & 4 & 3 & 3 & 2 & 2 & 7,05 & 6,57 & 4,48 & 3,48 & 5,55 & 5,88 & 20 & 9,09 \\
\hline
\end{tabular}

Source: Authors' own elaboration.

The concern for the importation of the virus is clearly found in Portugal, due to the connection with the former colonies. The Jornal de Noticias develops such a discourse on early (the first article registered dates from 17-12-1997) and constant dates (1998, 2000, 2003 and 2004). Despite the vaccination coverage in the countries of the Iberian Peninsula, the immigrant begins to be seen as a potential threat, the bearer of microorganisms that were already part of the past. In the regional pages of the Madrid edition of the El Pais of 03-07-2005, we found the headline: "Healthcare is preparing a specific vaccination schedule for poorly immunized immigrants. There are outbreaks of diseases that were virtually 
eradicated in the Community." None of these outbreaks was polio, but vaccination was reinforced. ${ }^{17}$

To the extent that the dates shuffled to achieve eradication (2000 and 2005) evidence the failed attempt, newspapers (and the $\mathrm{WHO}$ ) provide explanations in the form of news. The discourse focuses on the easy transmission of the virus and the vaccination campaigns as the only way to stop it. The risk for neighbouring countries becomes an image of global threat. In 2004 we find similar headlines in Portugal and Spain: "WHO alerts to poliomyelitis outbreak in Africa" (Público, 23-062004), "WHO warns of expansion of the biggest polio epidemic of the last few years in Africa" (El Mundo, 24-06-2004). Meanwhile, the Jornal de Notícias considered that the outbreak in Darfur (Sudan) posed a high risk of infection (Jornal de Notícias, 10-10-2004). One of the most descriptive headlines of this discourse can be found in the El Mundo: "Polio reappears in 17 countries / Experts located the source of new outbreaks in Nigeria, where there was a boycott of the vaccine in 2003 / This year, Yemen and Indonesia are the most affected" (El Mundo, 11-5-2005). The article, signed by Rosa M. Tristan, renders account of the problems in the region of Kano, in Nigeria, which led to an outbreak that spread across the north of the country and from there spread to neighbouring countries and other Islamic countries, due to pilgrimages to Mecca. It is quite interesting to transcribe the way it is narrated: "Two years ago, the most extreme Islamic authorities launched a boycott against the childhood vaccination campaigns which WHO and UNICEF had begun. They were accused of endangering their children in an international conspiracy against Muslims and refused immunization for months, until they are convinced that vaccines were reliable" (El Mundo, 11-52005, 38).

The way the Nigerian outbreak is interpreted also shows different journalistic uses of polio, closer to metaphor rather than objective information. The association between polio and Islam occurs more clearly in the Spanish press, and specifically in the newspaper El Pais, which will associate Nigeria with polio triple the times the El Mundo did so (45 times versus 15), having a clear position in the Nigerian antivaccination posture, promoted by fundamentalist religious leaders as the source of the spread of the epidemic. Beyond this explanation given by the WHO itself, the different distribution of the same in the two countries, and especially between the two Spanish newspapers, requires careful reflexion.

The chronological analysis of the association between polio and Islam that makes El Pais evidences that, of the 54 articles analysed, the term "Islamism" only appears in articles on polio as of July $29^{\text {th }} 2003$ (Fig. 6) . None of the 30 previous

17 Otero García, Laura, Aproximación a las representaciones sociales sobre la salud de la población inmigrante en el discurso periodístico en prensa escrita española (2000-2006). Madrid, 2011. 
Table 3. Relationship between polio and Islam (1995-2009)

\begin{tabular}{ccc}
\hline & EL PAÍS & EL MUNDO \\
\hline Islam* $^{*}$ & 17 & 2 \\
Fundamentalis* $_{\text {Integris* }}$ & 0 & 1 \\
\hline TOTAL & 4 & 0 \\
\hline & 21 & 3
\end{tabular}

Source: Authors' own elaboration based on El País and El Mundo.

Figure 6. Relationship between polio and Islam in El Pais (1995-2009)

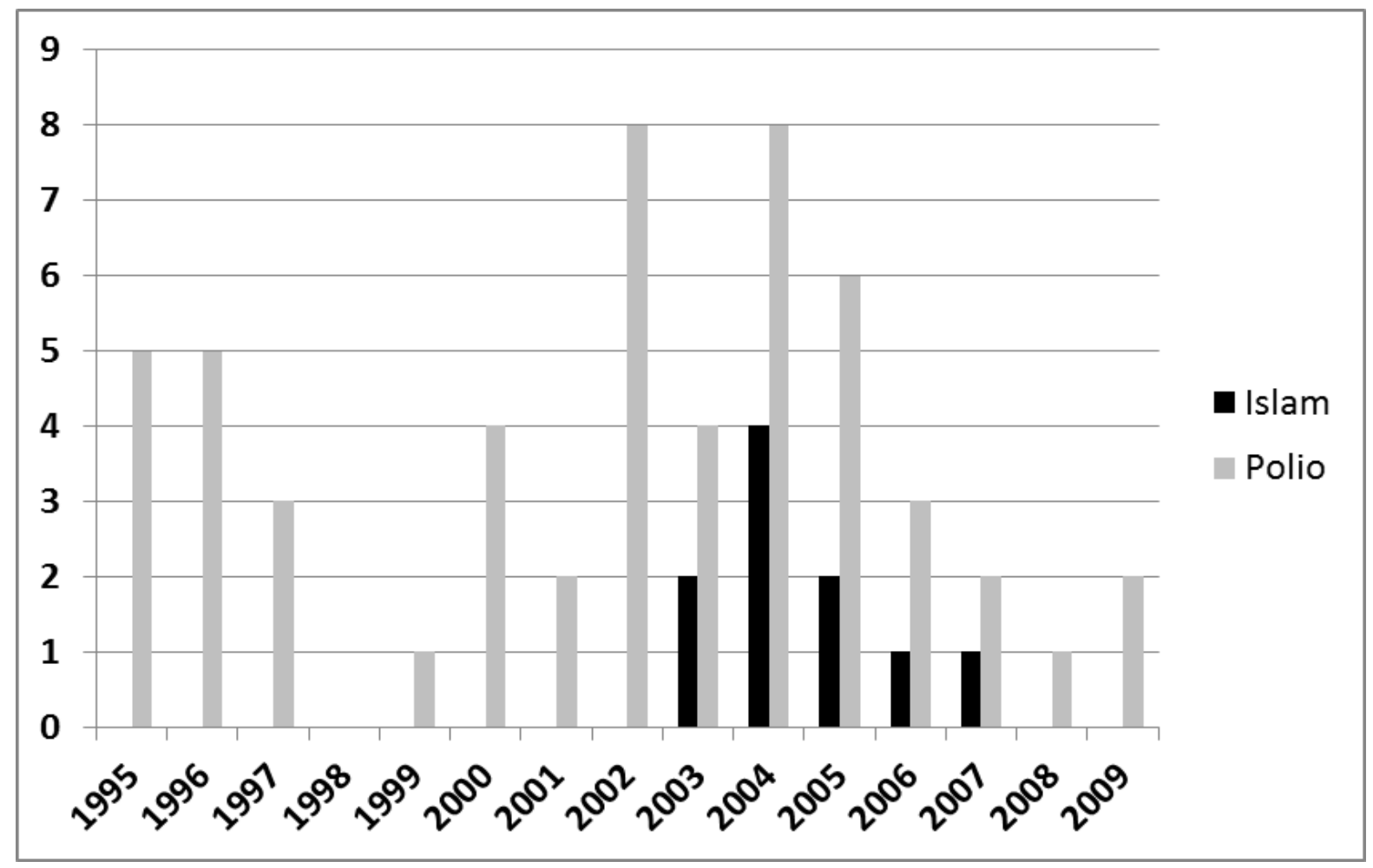

Source: Authors' own elaboration.

articles linked both concepts, in contrast with $45.83 \%$ of the 24 posterior articles which did so. Some of the headlines raise no doubt, with the use of terms such as Islamists (fundamentalists, radicals) and boycott. ${ }^{18}$ An explicit statement dated 0203-2004 assimilated fundamentalism with Islam and introduced the guilty verdict: "Up to seven countries have registered polio cases, in the last year, because of the Islamic authorities in northern Nigeria".

While the first article offered more objective information (the Council of the Nigerian Sharia considered that vaccines contained the HCG hormone which would prevent fertility), the latter showed the Nigerian anti-vaccination devoid of background or context, prevailing only the image of fundamentalism. The article dated 30-03-2006, signed by Celia Dugger and Donald McNeil Jr. of the The New York Times (which would weekly select news from El Pais for publication in

18 López Gil, Pablo, Miguel Otero Iglesias, Miguel Pardo Pereira y Miguel Vicente Mariño, dirs., La imagen del mundo árabe y musulmán en la prensa española. Sevilla, 2010. 
Spanish) allows acknowledgement of a full, more simplistic and radical construction, of how the Nigerian Sharia offered opposition to the vaccination of the West: the conspiracy theory had been sponsored by Dr. Ibrahim Datti Ahmed (Chairman of the Supreme Council of Sharia in Nigeria, political and religious opposition in northern Nigeria) during the 2003 elections when he did not obtained a position in the Department of Health of the secular federal government of the country.

It is noteworthy that the only article in the El Mundo that clearly associates fundamentalism and anti-vaccination against polio also comes from foreign signatories, in this case Declan Walsh (The Guardian): "Fundamentalism boosts childhood polio in Pakistan / Thousands of parents refuse to vaccinate their children against the disease because some clerics tell them that this is an American plot to sterilize them" (El Mundo, 16-02-2007). Its structure is very similar to that which had already been seen and, in the text, the Nigerian Anti-vaccination reappears as the source for the virus spreading to twelve countries which were free of polio.

Notwithstanding, it will be the newspaper El Pais to give some clues to understand the problem: the articles dated 28-10-2003 and 23-06-2004, signed by Emilio de Benito (specialist in health matters) refer that in 1996 Pfizer carried out a clinical trial of a drug against meningitis in northern Nigeria (the main opposition to the vaccine), in the region of Kano causing 11 deaths and serious sequelae in 200 other children; something which the Portuguese newspaper Público three years later echoes ("Nigerian state of Kano sues Pfizer for trial of drug which victimised children" Público, 6-6-2007). Only at the end of a short article of 31-07-2004 can we find another element to understand the anti-vaccination: "Doctor Bashir Sadiq Wali, head of the team in charge of the confirmation of the condition of the vaccines, states that the suspension of the campaign is due to 'the public mistrust towards the West" (El Pais, 31-07-2004).

The different attitude among Spanish newspapers must be related to the events which were taking place in their own country: the participation of Spain in the invasion of Iraq rendered the country to be considered as target of jihadist terrorism, with the appalling consequences of the attack which took place on 11-052004. The different political views of both newspapers about the authorship of the Atocha terrorist attack should be considered as determinants in the development of such different discourses regarding polio and its expansion: from the perspective that Islamic fundamentalism is "the" threat, polio works as representing it. 


\section{A Two Faced Science}

The information on polio in the analysed press offers different aspects once their presence in the West is contemplated and especially in the countries studied. Here information is usually linked to scientific aspects, primarily those involving new contributions, but also those which entail risks, feeding a wide range of antivaccination theories which, without any higher reliability than that seen in developing countries, are informatively treated with greater respect.

Virus, vaccine and vaccination become models: the virus for its structural simplicity; the vaccine for its efficiency; and vaccination as an example of great global project which will lead to eradication. This aspect does not motivate articles nor is it present in the headlines, but it is constant when analysing the operating framing. For this reason cross references are very common when any other issue is dealt with, given that polio provides for a comparison element known to readers and easily assimilated; it is therefore cited with reference to diseases such as HIV / AIDS, influenza, malaria, smallpox, tuberculosis and leprosy, in order of highest to lowest frequency.

\section{The Poliovirus}

On July $12^{\text {th }}$ 2002, the Jornal de Noticias collected the opinion of American researchers about the danger of the production of the poliovirus in a laboratory. Those opinions were also reported by Público (12-07-2002) and on the following day, by El Mundo and the El Pais, which gave it front page coverage: "Pentagonfunded scientists created, in a laboratory, the poliovirus." The subtitle left even clearer what the piece of news intended to convey: "The experiment, with DNA purchased by mail, raises the spectre of bioterrorism." The article rendered account of the publication in the Science Magazine of the work by Eckard Wimmer's team in the synthesis of the poliovirus from the available genetic information on it and emphasized the most dangerous aspects of the achievement. Wimmer himself understood, in an article dated 12-10-2002, the causes for alarm: "The project was approved in 1998, it had nothing to do with September $11^{\text {th }}$. If we had we published the results before that date, they probably wouldn't have caused such an outrage. The fear of bioterrorism allowed emotions to run wild." An increasing fear throughout the West. ${ }^{19}$

On April $15^{\text {th }} 2003$, the Jornal de Notícias abounded in the connection between polio and bioterrorism, with no need for synthesis, while reporting that a laboratory

19 Hecht, Alana, Polio. New York, 2009. 2nd ed., pp. 82-100. 
had been looted from Iraq and free access to the virus had been achieved. In contrast, the El Mundo, which initially gave little importance to the artificial creation of the poliovirus (middle column on the 13-07-2002), explored the possibility of bioterrorism only after the publication of an article, on the 08-102004, about the creation in a laboratory of the virus of the Spanish flu of 1918. However, the most serious consequence of the achievements of artificially producing a virus was only featured in the headlines of El Pais on the 12-10-2002 "Never again will it be possible to eradicate a virus." Eradication presents itself as utopia and vaccination as a continuous need.

\section{The Vaccine}

For the press, the polio vaccine is the one administered directly, with a few drops ingested orally, although paradoxically it never shows the name of Albert Sabin, despite constantly having the name of Jonas Salk connected to it, as if it were a surname, the "discoverer of the polio vaccine." This connection goes further beyond Salk himself extending to his Institute, so that all studies on a vaccine against HIV were hopefully associated with polio, but always marking the difference between the simplicity of this vaccine compared to the highly complex ones which immunize against plasmodium or HIV. Other informative occurrences do not have any special meaning because they appear jointly with the periodic announcement of the vaccination schedules and their alterations, such as the introduction of the hexavalent vaccine, although it was advertised for the convenience of reducing "sticks" but without analysing the reasons and consequences of changing an attenuated virus for an inactivated one. ${ }^{20}$

It is precisely this relationship with HIV that feeds one of the critical theories towards vaccines which has occupied more space in the press. It was disclosed by journalist Edward Hooper in his book The River (1999); he considered that during the tests for an oral polio vaccine (performed in the Belgian Congo by Hilary Koprowski, for the Wistar Institute in Philadelphia) would have unintentionally introduced simian immunodeficiency virus in the new vaccine. The El Mundo did not hesitate to give it the entity of article with a sensationalist title: "A laboratory in the USA could have created AIDS", which, although being referred in the subtitle, is subsequently fostered by the drafting of a text which begins with "AIDS is the work of man" (El Mundo, 16-11-1999). In 2000 studies were performed which

20 Beale, A. John, “The Development of IPV,” pp. 179-187 in Stanley A. Plotkin, ed., History of Vaccine Development, New York, 2011. 
dismissed this origin and refuted this theory, ${ }^{21}$ of which both the El Pais and the Jornal de Notícias gave information, this time as articles. The El Mundo also mentioned it, but only with a brief 11 -line article.

Three other links were established between the polio vaccine and other diseases. The contamination of the polio vaccine with a virus found in apes (the SV40) was mentioned in articles like the one that dealt with the xenotransplantation by exposing the possibility of transmitting animal viruses to humans with unpredictable consequences (El País, 28-01-1998, 37). José Antonio López Guerrero, a virologist at the Autonomous University of Madrid, wrote an article in the El Mundo about the collateral damage of vaccines and echoed the studies of the Samaniego group which placed the SV40 transmitted by the polio vaccines as the source for lymphoma of unknown etiology (El Mundo, 17-06-2004).

Without having a specific character for polio, but rather for vaccines in general, some articles appeared on the mercury content of thimerosal - used as a preservative in vaccines - as the cause for autism (El País, 07-07-2005, sup. 5). The polio vaccine was one of the vaccines which, for this reason, the Americans antivaccination began to reject. The information came from the NYT, from which the El Pais offered the Spanish version of some selected articles. Nevertheless, the year before, the El Mundo had published an article in which, supported by scientific publications, the relationship between vaccines and autism or Type I diabetes was discarded (El Mundo, 03-04-2004).

A much more alarming situation which was reflected in the press of both countries in an immediately and simultaneous manner was that of the noncompliance, by the pharmaceutical company Medeva, of the European norm on bovine spongiform encephalopathy, which prohibited the use of bovine derivatives in the process of making medication, given that this disease, active in the cattle, could be transmitted to humans. Medeva have marketed bovine serum used in the preparation of vaccines against polio, which would open a possibility for the production of Creutzfeldt-Jakob disease. Although with some nuances, the three newspapers presented headlines on October $21^{\text {st }} 2000$ : "The UK withdraws a polio vaccine" (El Mundo), "London and Dublin remove, out of fear of the 'mad cow' disease, a vaccine applied to thousands of people "(El Pais), "Vaccines against polio are safe in Portugal" (Jornal de Noticias). While the Portuguese headlines sought to reassure, the headline in the El Pais fired alarms.

The amount of information about vaccine risks and potential sustaining theories of anti-vaccination is not only not ridiculed as we have seen in the case of Islamic countries, but they are even sponsored, but ultimately refuted or a compensatory image of the benefits of vaccination is offered. The possible influence of the agenda

21 Koprowski, Hilary and Stanley Plotkin, "History of Koprowski Vaccine Against Poliomyelitis," pp. 155-166, in Stanley A. Plotkin, ed., History of Vaccine Development, New York, 2011. 
and framing is not manifested in actions consistent with the alarm or uncertainty that could have been generated, but the percentage of children vaccinated rises from $90 \%$ to almost $96 \% .{ }^{22}$ This fact allows us to question the power of influence of the media agenda against a reality with a standardization supported by pragmatism.

\section{Polio after Vaccination}

The oral vaccine and its role in immunization save themselves with a balance in their favour within the information provided by the press. However, the risks of vaccination with attenuated viruses (such as the oral vaccination) always involve a small risk of producing what is called vaccine associated paralytic polio (VAPP). Another issue widely discussed, denied and disputed, is that of mutations of the virus in the environment and the recovery of its infecting and paralytogenic power.

Until 2000, El Pais published three articles (out of 14) which questioned vaccination: a brief note dated 23-10-1995 conveyed the American CDC recommendation to move on to the injectable vaccine in consequence of the cases of paralytic post vaccine polio presented; this is confirmed in another article dated 22-06-1996 and crowned with an article about a case of post-vaccine polio seven years after having been vaccinated (El Pais, 19-07-1997), all of which in the United States.

The dates and the type of articles were earlier than those published in the $E l$ Mundo, which only reports about the VAPP from 2000 onwards, with a good article by Carlos Marina Lopez within a long report dedicated to polio and its eradication (El Mundo, 12-04-2000). On the 25-11-2000, the column by Deborah Mackenzie, of the New Scientist, was reproduced; it reported on Mahoney varieties of the poliovirus in the French sewage and the risks involved. Some risks, such as those in the Dominican Republic and Haiti. ${ }^{23}$ in that same year and in 2001, where an oral vaccine caused an outbreak of polio, as confirmed by ScienceXpress ( $E l$ Mundo, 16-03-2002). It is noteworthy that all references of polio cases caused by the vaccine are backed with the signature of experts.

This important element of the persistence and outbreaks of poliomyelitis due to mutations of the virus (either the wild poliovirus or the vaccine virus) do not develop a reading that can taint the pro-eradication discourse: although the El Pais reported, on 12-10-2007, on a mutation of the virus in Nigeria, only the last article analysed in the El Mundo, a loose one which invites to further the information on the website of the newspaper, published on 29-09-2009, recognized one of the

22 Vigilancia de la Parálisis Flácida Aguda. Informes 2002-2012. Madrid: Centro Nacional de Epidemiología, 2009, 7.

23 Seytre, Bernardand Mary Shaffer, The death of a disease: a history of the eradication of poliomielitis. New Brunswick, 2005. 
problems: "since 2000 there have been 383 cases of polio caused by the vaccine in 11 countries."

We can interpret that this theme is not coincident with the main axes of support to the eradication followed by newspapers analysed and that the dates of 2000 and 2005 as keys to get it will function as deterrents for the publishing of critical articles. The pro-eradication discourse of the early years, full of triumphalist optimism, silenced the reflections on the "collateral damages" of vaccination and, given the difficulties in achieving the goals of the WHO, the new discourse which held the Islamist anti-vaccination responsible for the failure only offered a monochromatic interpretation of the motives.

\section{The Personal Dimension}

\section{Gallery of Famous People with Polio}

Due to all that has been exposed, we can consider that polio in Spain and Portugal was associated with a distant and impersonal image, mainly consisting of numbers (of disease, of vaccine doses administered, of vaccinated children, of money invested or the need to achieve eradication). However, the strong imprint of the epidemics in the fifties survived in certain forms that show the lasting image of the polio created at that time.

The term poliomyelitis sometimes appears outside the health contexts to represent other ideas symbolized by polio, the most frequent of which are paralysis or immobility. One example for that is a sports article in which reference is made to a team that showed "superiority against an opponent with football polio and therefore limp since the race began" (El Mundo, 22-02-2004). This use of the term in one of the sections is interesting, that of sports, inasmuch as it is common to find references to athletes who suffered from polio. It is not only about the information on specific competitions and the Paralympic Games, but uses of another great stereotype of a person with polio as an example of continuous effort and overcoming difficulties. In this sense, the sports pages continuously associate Wilma Rudolph, Haile Gebrselassie or "Garrincha" who suffered from the condition and the tenacity with which they fought against adversity.

The pros and cons of praising effort, while standardization of a single desirable and possible principle for the social integration of people with polio sequelae, are unmasked in the use of language when referring to people. A comparison between the usage the two Spanish newspapers make of the words "discapacitado" (disabled) or "minusválido" (literally "with less value", handicapped) when referring to people 
with polio, shows that the first term is used most frequently by the El Pais $(54.48 \%$ of the time compared to $49.51 \%$ ), while the label of "handicapped" is used by the El Mundo in $83.02 \%$ of cases (compared to $61.90 \%$ of the El Pais). These differences in the implementation of the conventions of the "politically correct" language lead to the fact that the El Mundo even uses words like "diminished."

The visibility of people who have had polio and had or have consequences arising therefrom, may be considered, according to the framing, in three different areas, but all of them defined according to the individual characterization, providing stereotypical features built in the collective imaginary surrounding the disease and those who suffered from it. The first scope and the more abundant one is that of celebrities in whose biographies the episode of having suffered from polio is constantly repeated. It is not only about the cases of Franklin D. Roosevelt or Frida Kahlo, but also a wide range of artists with not apparent polio sequelae, but for whom the condition is always associated with long time loneliness and isolation during their childhood, as well as personality traits which include a strong willpower, perseverance, the ability to overcome or the empathy for those who suffer. In some cases the predominant image is that of pain and suffering (the model of Frida Kahlo is reproduced in Chavela Vargas or Tanaquil Leclerq), in others that of overcoming it (the FDR model is shared primarily with athletes). Most notable is the absence of references to Portuguese or Spanish celebrities that had polio. We have only found a reference to the harm suffered by the singer Martirio (El Pais, 19-05-2002, 239) or a brief comment on the television comedian Mariano Mariano (El Mundo, 22-02-1997, 48); apart from the obituary of the music critic Gonzalo Badenes (El País, 22-09-2000, 40) or that of the writer Vicente Tortajada (El Mundo, 07-06-2003). This absence is not exclusively attributable to the press, but rather to the self-perception of those personalities about the stigma and discrimination from a hostile environment, which is common to others with minimal sequelae and greater integration capabilities that chose to disguise them and silence their origin.

The environment has hindered the personal and professional development of people with polio sequelae, far more when they are more severe, reducing the number of those who then achieve success. The media in Spain enable us to identify a second type that of people who are known for their activism in social movements associated to disability. In such cases we find that a significant proportion of its leaders were affected by polio, something consistent with the role that people with polio sequelae played during the Transition in the vindication of the rights of people of functional diversity. ${ }^{24}$ In the Portuguese press there are only references to polio cases of celebrities, always foreigners, highlighting the main problem in the news agendas: the weak existing Portuguese association movement

24 Rodriguez, 2012. 
was not been able to raise awareness in the media to include the issue in their agendas, which prevents the provision of information which allows the awareness of the problems caused by polio.

However, the third scope of the relation between celebrities in the media, and the affectation by polio, is a part of a style of articles which oscillate between the denunciation of social exclusion of the disabled and sensationalism, which is unevenly treated according to each newspaper. Here, the use of language, which we referred, is much more significant and polio sequelae are yet another element in the portrait of poverty and social exclusion.

One must mention polio as a feature of the person which it transcends due to the political use which the news agenda grants it. This is the case of a demonstration by the Asociación de Víctimas del Terrorismo (Association of Victims of Terrorism), in which a man suffering from polio participated in a wheelchair and was publicly accused by two socialist leaders to impersonate a victim of attack. The El Mundo repeatedly reported the case between 16-12-2006 and 14-02-2007, appearing in 16 entries, whereas in the El Pais we only find this reference once. This uneven use converts Joaquín Merino into the person with polio most quoted by the El Mundo about the origin of their disabilities, above FDR and Frida Kahlo.

\section{The Post-Polio Syndrome (PPS)}

The invisibility of people with polio and the agenda of each newspaper are a vicious circle difficult to break and with serious consequences on misinformation of people with polio sequelae on the health problems they may face. In the reporting period, neither the Jornal de Notícias nor the Público dealt with the post-polio syndrome (with the exception of a reference in the Jornal de Noticias, in 2007) we have not been able to confirm its presence despite the existence of an association of people affected by the disease, the Associação Pós-Polio de Portugal (Post-Polio Association Portugal), which even held two meetings and published three books on the matter. Its short life (1998-2007) and its intervention scope too close to Évora minimized its influence and thwarted its attempt to incorporate the post-polio syndrome into the agenda of the Portuguese press. ${ }^{25}$

On the other hand, the Spanish newspapers analysed in this study provided the first reference to the PPS in 1997, in an article in which, for the first time, we can find the word in the Spanish press, in an entry: under the title "The benefits of the magnet," the article focused on magnet therapy studies conducted by Carlos Vallbona, at Baylor College of Medicine, in Houston. The investigation had been conducted with patients of PPS and, of the three columns of the article, the journalist Myriam López Blanco spent one explaining what the disease was ( $E l$

25 Rodríguez, Ballester, Guerra, 2013, p. 251. 
Mundo, 27-11-1997). The El Pais gave the same information in the following year (20-07-1998) and the El Mundo still continued to report the issue on two other occasions (16-06-1998 and 11-03-2000), the last one to mention studies which refuted the usefulness of therapy. The only other initial mention made to PPS in these year will be a reference to suffering by Arthur C. Clark (El Pais, 01-11-1999 and, belatedly, the only reference to PPS in the Portuguese press, in the Jornal de Notícias, in 2007).

Nevertheless, the references to post-polio syndrome are rare (only 21 in 15 years) and only from 2000 onwards is it located in Spain. El Pais doubles the number of entries regarding the El Mundo (15 versus 7) and when the subject is approached it usually is so extensively (7 articles compared to only 1 in the El Mundo, quoted on Vallbona, in the United States). We must also consider that the articles in the El Pais account for $50 \%$ of the references made to the PPS and almost $13 \%$ of all the articles on polio (Table 4).

Table 4. Entries and articles about polio and PPS (1995-2009)

\begin{tabular}{|c|c|c|c|c|c|c|c|c|}
\hline \multirow[t]{2}{*}{ Año } & \multicolumn{2}{|c|}{ Entries polio } & \multicolumn{2}{|c|}{ Artícles polio } & \multicolumn{2}{|c|}{ Entries PPS } & \multicolumn{2}{|c|}{ Articles PPS } \\
\hline & EP & EM & EP & EM & EP & EM & EP & EM \\
\hline 1995 & 35 & 23 & 5 & 1 & 0 & 0 & 0 & 0 \\
\hline 1996 & 34 & 33 & 5 & 3 & 0 & 0 & 0 & 0 \\
\hline 1997 & 26 & 29 & 3 & 4 & 0 & 1 & 0 & 1 \\
\hline 1998 & 23 & 21 & 0 & 0 & 1 & 1 & 0 & 0 \\
\hline 1999 & 33 & 35 & 1 & 1 & 1 & 0 & 0 & 0 \\
\hline 2000 & 30 & 43 & 3 & 6 & 2 & 2 & 1 & 0 \\
\hline 2001 & 25 & 20 & 2 & 5 & 0 & 0 & 0 & 0 \\
\hline 2002 & 25 & 17 & 8 & 6 & 3 & 0 & 0 & 0 \\
\hline 2003 & 26 & 29 & 4 & 2 & 0 & 0 & 0 & 0 \\
\hline 2004 & 22 & 29 & 8 & 7 & 1 & 1 & 1 & 0 \\
\hline 2005 & 27 & 42 & 6 & 6 & 1 & 0 & 1 & 0 \\
\hline 2006 & 35 & 32 & 4 & 2 & 1 & 0 & 0 & 0 \\
\hline 2007 & 21 & 35 & 2 & 2 & 1 & 0 & 0 & 0 \\
\hline 2008 & 21 & 20 & 1 & 1 & 1 & 0 & 0 & 0 \\
\hline 2009 & 14 & 18 & 2 & 5 & 2 & 2 & 1 & 0 \\
\hline TOTAL & 397 & 426 & 54 & 51 & 14 & 7 & 7 & 1 \\
\hline
\end{tabular}

Source: Authors' own elaboration based on El País and El Mundo.

Notwithstanding, the chronological distribution of these articles evidences that the attention they received was directly related to the informational interest aroused 
Figure 7. Post-Polio Syndrome in El País and El Mundo (1995-2009)

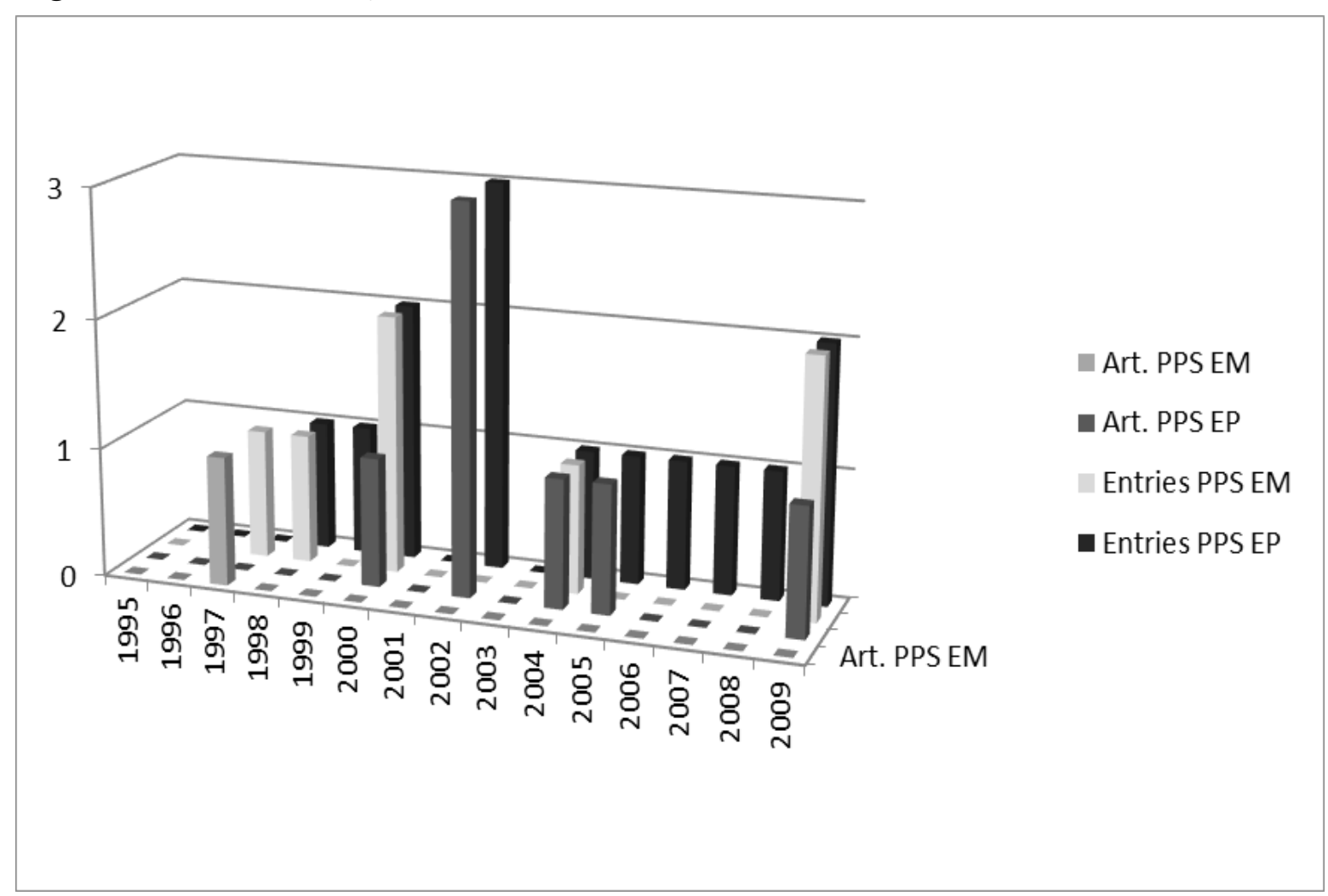

Source: Authors' own elaboration.

by polio at certain times. This is the case of the year of 2002, the year in which more references and articles were published on the PPS, but also the year when the certification of polio eradication was obtained in the European region and the artificial virus was produced (Fig. 7).

In the seven pieces of information from the El Pais classified as articles, we considered how the PPS was presented, either with more emphasis on polio and presenting it as a result thereof or focusing on the PPS as a current problem. As the number of articles was so scarce, the determining factor seems to have been the journalist. The first articles, signed by Gabriela Cañas, focused on a dramatic image of the vengeful return of the virus: "The post-polio syndrome, the revenge of a virus that the world is about to eradicate" (07-03-2000) "The post-polio syndrome strikes the survivors 30 years later" (05-02-2002). A different view compared to the posterior articles by Emilio de Benito, focused on the claims of those affected, "Congress demands support for those affected by the post-polio syndrome" (19-032002), "A judge asks if there is negligence of the State in 36.000 cases of post-polio" (18-07-2005).

It is important to bear in mind this presentation of the syndrome by the effect it has on the readers, and especially on those with polio sequelae. Only the first article of Gabriela Cañas clarifies that not all people will suffer (and endorses this perspective with rehabilitation experts, such as Ana Águila Maturana), whereas the second one presents the PPS as inevitable. The ambiguity present in scientific 
studies (thus, before a formerly described clinical entity, baptized in 1985, but only recently made official - in 2010 - there are no reliable case studies to enable a wellfounded prognostic) offers a large margin for speculation, which consciously or unconsciously, is used ever since the association movement for its claims. Here, it is important to consider the context, since most of the articles on PPS will dispense the testimony of health professionals and will be based only on the number of people affected and one of their associations (the Asociación Afectados de Polio y Síndrome Post-polio, AAPSPP, Association for the Affected by Polio and PostPolio Syndrome), demanding judicial accountability by the State for the cases of polio that could have been avoided and those of post-polio that could have been assisted and criticises oral vaccination with attenuated virus. ${ }^{26}$ Emilio de Benito renders account of the data provided by the association: facing the 30.000 affected by polio (according to the unreliable and incomplete official statistics of the Franco administration), the association sustains that there are 300.000 and applying the forecast of how many can come to develop PPS, it estimates there will be about 150.000 , a figure which the journalist turns into subtitle of the article. Nevertheless, the report made by the Agencia de Evaluación de Tecnologías Sanitarias (AETS, Agency for Health Technology Assessment), following the contrast of varied databases, had ciphered, in 2002, the existence of 42.651 people in Spain with some degree of disability derived from polio sequelae, which enabled them - applying the wider ranking of prognosis for the appearance of PPS in people affected by polio (between 22\% and 85\%) - to estimate that, in Spain, there could be between 9.383 and 36.253 people with the syndrome. ${ }^{27}$ These conclusions were presented in an article dated 30-07-2002, despite which the same article continues to include the figures estimated by the association, for anyone who had had polio but had not had paralysis may develop the dreaded PPS. Nevertheless, now in the headline the figures are those provided by the AETS.

It is interesting to contrast this framing of the El Pais with the one offered by the El Mundo for the first reference to the PPS at the national level, something which happens in the context of a comprehensive report on the eradication of polio in the world (El Mundo, 21-02-2004). The section is titled "Pain, fatigue and tiredness several decades after" and is signed by Isabel F. Lantigua, a reporter specialized in health matters. This fringe at the bottom of the page again is centred yet again on the information which comes exclusively from patients and specifically from the AAPSPP. More cautious regarding the figures, the final reference in the report by

26 Rodríguez-Sánchez, Juan Antonio, "La persona enferma como experta: los cambios sociosanitarios promovidos por el asociacionismo polio-postpolio en España," Estudos do Século $X X 12$ (2012a), 104-122.

27 Bouza Álvarez, Carmen , Ana Muñoz van den Eynde y José Ma Amate Blanco, Síndrome post-polio:Revisión de la literatura, situación en España y posibles líneas de actuación. Madrid, 2003. 
the AETS places the incidence between 10.662 and 36.253 affected. The perspective assumed by the journalist does not explore the past but focuses on the present and, specifically, on the problems arising from the lack of knowledge on polio and PPS by most health professionals, which makes the diagnosis harder to achieve.

This agenda and framing of the El Pais towards the PPS had another clear effect on the public agenda and, particularly, on those affected by polio as it promoted the active search for information through the associations. It is said that the articles, though rare, were widespread. All but one contained a photograph of the president of the AAPSPP, Lola Corrales, and in the first four there was the URL address and the phone number. The positioning of the newspaper in favour of associations is also seen through the endorsement of the "politics of numbers" used by the associations affected by diseases of low prevalence, presenting to the headlines higher prevalence estimations. ${ }^{28}$ The effect on the public agenda was observed by the AAPSPP itself, because after each occurrence in the press they were contacted by people who thought they could suffer from the syndrome, according to testimony from the president herself. Thus not only is the power of the media agenda ratified, but also the strategies needed for the associations of those affected are shown in order to get the disease introduced. ${ }^{29}$

\section{Reality and News: Chronological Analysis}

The lack of information about post-polio syndrome and the rare mentioning of the problems experienced by people with polio sequelae are not the only maladjustment between reality and what is considered news, and that which becomes part of the news agendas in Portugal and Spain. The evolution of the news during the period analysed reveals common trends, although with some variations according to the newspaper.

In some countries with no new cases of polio for more than some years, the international health agendas marked the Iberian news agendas. Therefore we can establish a separation into two periods, whose dividing date would be the year of 2000, a year full of symbolism and the first of those considered by the WHO as the year when polio would be eradicated from the world. In fact, both the entries and

28 Rabeharisoa, Vololona, Michel Callon, Angela Marques Filipe, João Arriscado Nunes, Florence Paterson and Frédéric Vergnaud, "From 'politics of numbers' to 'politics of singularisation': Patients' activism and engagement in research on rare diseases in France and Portugal," BioSocieties, 2014, 1-24, in http://www.palgrave-journals.com/biosoc/journal/v9/n2 Ipdf/biosoc20144a.pdf [12-06-2014]

29 Talley, Colin, "The Combined Efforts of Community and Science: American Culture, Patient Activism, and the Multiple Sclerosis Movement in the United States," pp. 39-70, in Randall M. Packard, Peter J. Brown, Ruth L. Berkelman and Howard Frumkin, eds, Emerging Illnesses and Society: Negotiating the Public Health Agenda, Baltimore, 2004. 
the articles produced in this first phase are encouraged by the announcement by the WHO on this deadline for the eradication: in 1995, the WHO chose as moto for the World Health Day "A World Without Polio" and the following year the virology congress held in Toledo offered some titles to the press which occupied the front page of the El Pais in 13-05-1996 ("Polio and measles soon be eradicated worldwide"). Failing to announce eradication on the due date, the El Pais also turned into news the fact that "The poliovirus has disappeared from Europe" ( $E l$ Pais, 26-12-1999), after one year elapsed with no cases reported in the European region. Meanwhile, the El Mundo put corollary to this first phase of optimism devoting a large report on polio in its supplement "El Cultural" of 12-04-2000, with two articles, one on "The End of Polio" and another on "New vaccines", respectively signed by Jorge Alcalde and Carlos Marina López,

It is necessary to focus the analysis for this early period, in the Spanish case, on the articles, as the entries are increased by the announcements made by ALPE of their charities, which are repeated on successive days. However, both entries and articles evidence a marked decline in 1998, when no article on the subject is published. This seems to reflect how the information shown was connected to the campaigns by international organizations.

This relationship is clearer in the next period, marked by the failed first announcement of eradication in 2000 and a similar failure in the goal set for 2005 . It is important to correlate the articles which the press dedicated to polio with three parameters which enable us to know what was happening with the disease, in the world: the number of reported cases, the number of countries reporting cases, many of them considered of endemic polio and finally how many of the cases reported did it in countries with endemic polio and how many in those where it was not. The following three graphs evidence such evolution. 
Figure 8. Polio cases by wild poliovirus in the world (2000-2009)

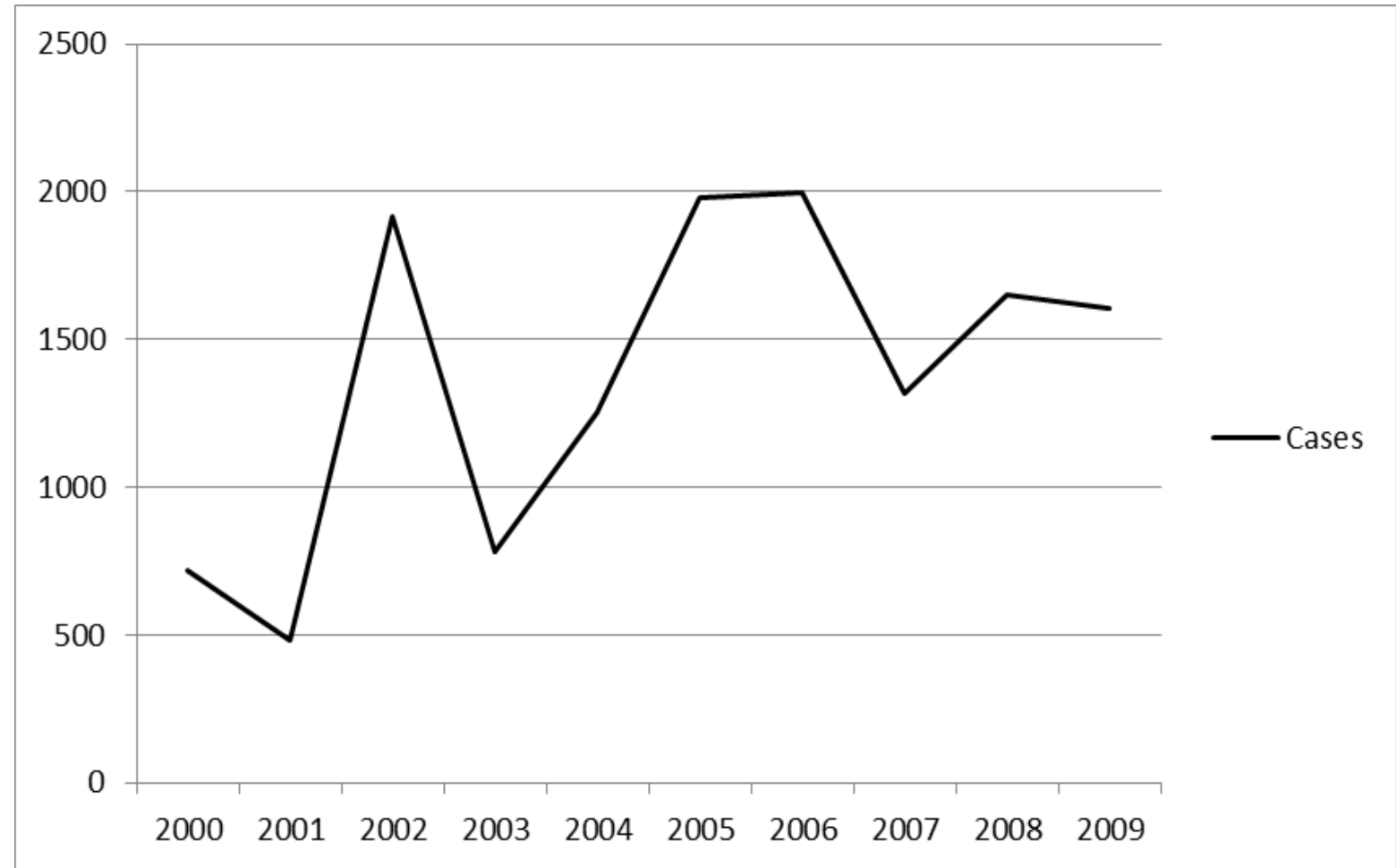

Source: Authors' own elaboration based on Global Polio Eradication Initiative.

Figure 9. Polio cases in the world: endemic countries (2000-2009)

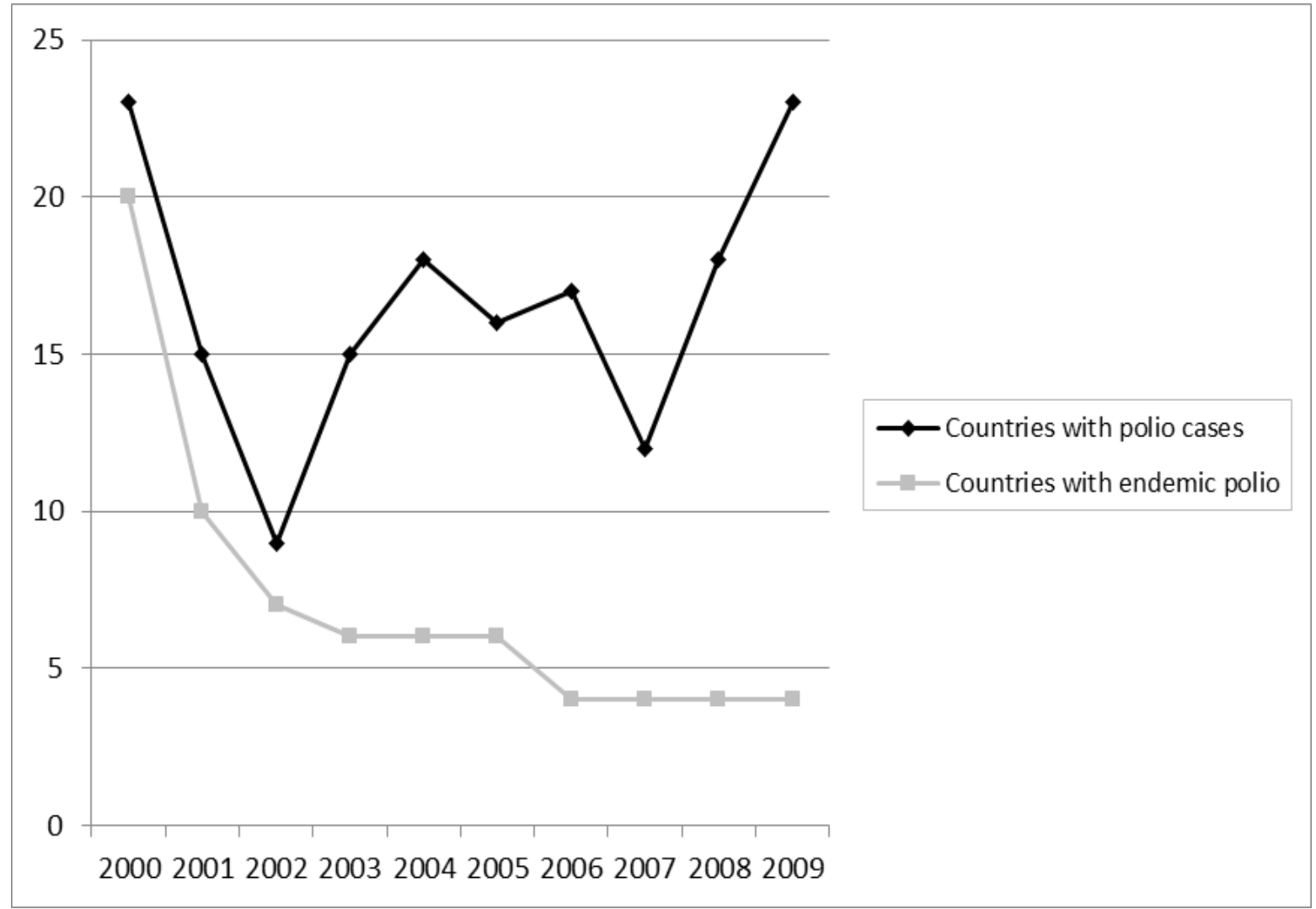

Source: Authors' own elaboration based on Global Polio Eradication Initiative. 
Figure 10. Polio cases in endemic and non-endemic countries in the world (20002009)

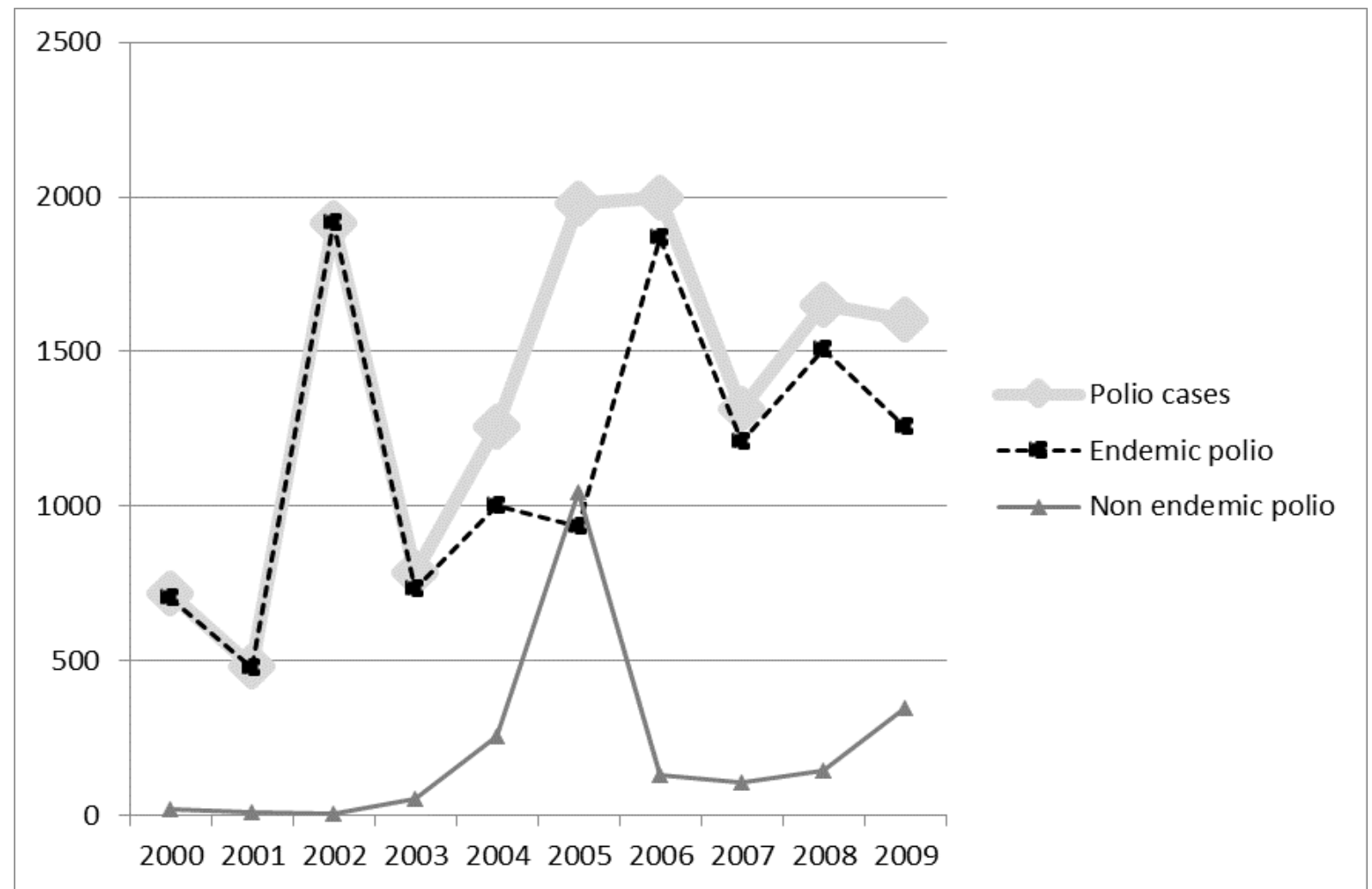

Source: Authors' own elaboration based on Global Polio Eradication Initiative.

The year of 2002 represented an increase of cases of polio in countries where it was considered endemic, although the number of countries with polio cases was the lowest of the period, with only 9. That was a seeming paradox: the following year the number of polio cases worldwide decreased due to the vaccination campaigns carried out, but polio had spread to other non-endemic countries, in a process that continued until the end of the period, with the exception of 2007, ascending from 15 in 2003 to 23 countries in 2009 (Fig. 9). The number of polio cases managed to be reduced in 2007 and its growth was slowed down, minimizing its appearance outside the countries with endemic polio. Two dates are noteworthy: the high number of cases of polio in 2005 and 2006, noting that in 2005 there were more cases in non-endemic countries than in endemic ones and, above all, the situation in 2006. In 2006 the number of countries which declared polio increased and the highest number of polio cases (1.997) was registered, almost everyone in endemic regions where there was an alarming increase (Fig. 10).

These extremely discouraging figures on the chances of eradicating polio, no longer on the announced dates, but in a near future, were not reflected in the production of news, as shown in the chart below, but rather in the removal of the latter (Fig. 11). In fact, 2006 is one of the years with fewer articles, a coincidence verified in the four newspapers. 
Figure 11. Articles about polio in Spanish and Portuguese newspapers (2000-2009)

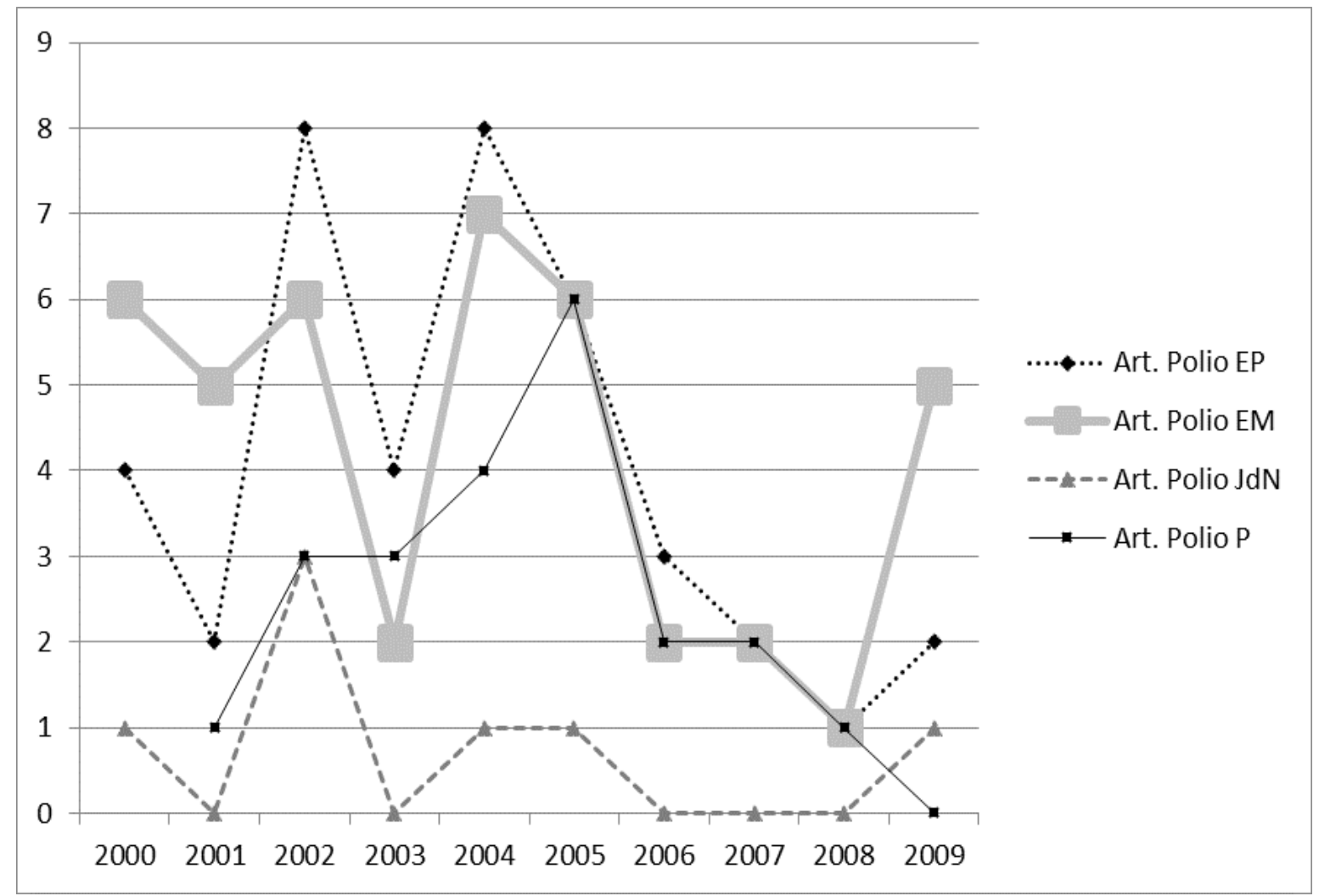

Source: Authors' own elaboration.

The informative peaks of 2004 and 2005 are related, as did the prior in 2000, to the goal of eradication and the news agenda of the international organizations with a clear strategy of alternating alarms and triumphant hope. As an example we have the articles published in 2004 in which the WHO reported the largest polio epidemic in Africa, with an expansion into countries where it was eradicated (Público, 23-06-2004, El País, 23-6-2004, El Mundo, 24-06-2004), and only two months later, the optimistic headlines announcing the elimination in 2005 according to the same WHO (Público, 05-08-2004; El Mundo, 06-08-2004).

The informative peak of 2002, however, does not correspond with what might seem a priori, as the most important event: that of obtaining the certificate of polio eradication in the European region. It is true that the newspapers from both countries provided that piece of information on 22-06-2002 in the form of articles, but with no greater continuity in other articles or entries. The abundance of articles and entries in 2000 and 2002 had a close relationship with the aforementioned social alarms: in 2000 it was the relationship of the vaccine with the origin of HIV or with the transmission of "mad cow disease" and in 2002 the artificial synthesis of the virus in a laboratory and speculation about bioterrorism.

The striking increase in articles in the El Mundo in 2009 is apparent, since four of the five articles have been classified as such because they had the term polio in 
the title or intro, although the content only tangentially relates to the object of study.

The evolution of information in the press about polio also offers, in the analysis of its contents (and silences), a chronicle of disappointment: with a marked optimism and confidence in the eradication which is held until 2005, the second failure means entering a phase of disinterest in the subject in which the reference to eradication is part of a stereotyped discourse. The minimal attention to late effects of polio in Spain and Portugal clearly shows the lack of interest and there is only a resort to the problem of PPS to build a comprehensive discourse and therefore subordinated to the ephemerids.

\section{Concluding Remarks}

The disappearance of polio from the countries of the Iberian Peninsula, in the late eighties, led to an immediate and desired forgetfulness of the disease. For Portugal, polio cases were exceptional already in the decade of the seventies and for Spain they began to be so in the following decade. Polio and its sequelae were no longer on the agenda of the media to the point that the achievement of the certificate of polio eradication in the European region, granted by the WHO in 2002, had little impact in the newspapers of both countries, although this piece of news was placed in the article category and appeared simultaneously in all. But for those dates, the news about polio already had to include an explanation on what the disease was and what were its consequences.

This context led to the fact that information about polio came from other countries where they still continued to be produced and, therefore, the agendas of the analysed newspapers were directly related to the communication policies of international organizations fighting for the eradication of disease. Thus the international discourse about polio followed the guidelines of the reporting agencies of the $\mathrm{WHO}$, with its messages of encouragement, hope, fear or disappointment, according to the evolvement of morbidity worldwide. Therefore, polio became a disease of poor and distant countries from which it was possible to eradicate it through international cooperation and development programs. Until the beginning of the XXI century, the discourse of the media on polio was optimistic and confident in science and in the imminent eradication, a discourse which changed after the last missed deadline in 2005 and which transformed information on polio into a tell-tale silence, for the cases of polio in countries considered endemic remained a serious problem, despite the fact that the transmission to non-endemic countries diminished, which reassured Western countries and excluded the disease from the news agendas. 
The global scope of the disease also shows different agendas in the two newspapers analysed. On the one hand, we find a different focus between the Spanish and Portuguese press on certain countries threatened by the spread of polio, this being greater in the Portuguese press and focused on the countries which were once colonies, especially Angola and Mozambique. This also explains their greater presence in the Jornal de Notícias, given its more popular character.

Furthermore, we also identified a different use of the discourse on polio in the world between the two Spanish newspapers that lead to the fact that the El Pais develops a discourse on the risk of expansion of polio as a metaphor for the threat of Islamic fundamentalism, a difference between the two Spanish newspapers coincident with their analysis on the Madrid terrorist attacks on May $11^{\text {th }} 2004$. Nonetheless, it is common for the considerations on the risks of each new outbreak of polio for the spread of infection to neighbouring and poorly immunized countries should turn into a veiled warning to the health risks of immigration.

Facing this focus on the global situation, polio in the countries studied was not given much attention, except to include it in the information on vaccination schedules. This dissociation of poliomyelitis in Spain and Portugal is undoubtedly connected to the disappearance of new cases, but it means that people affected and with paralytic sequelae, and even those who presented the so-called post-polio syndrome, are invisible. This is one of the major problems identified, as it establishes a vicious circle: post-polio syndrome is not reported because there are no diagnoses for it, leading to the affected people and the whole society to remain unaware of its existence and not to consider such a possibility. Let us consider that the PPS, like other rare diseases, force the patient (or their families) to acquire an active role in finding a diagnosis. In Portugal there was no news about the PPS (except for an occasional reference to it in the Jornal de Noticias), while in Spain, only the newspaper El Pais granted it some informative importance in those moments when polio was on the international agenda. Nevertheless, this fact allows us to understand the social role of the news agenda: the emergence of associations in the Spanish press influenced the agenda of a particular audience, that affected by polio, and strengthened its organization; however, the absence of the Portuguese association of PPS in the news agenda hid the movement, which led to the persistence of ignorance about the syndrome and, consequently, an extreme associative weakness. It is thus confirmed that the media (among other means of communication) determines the low relevance / importance that the public grants to the subject and determines the content of its thought.

This consideration of those affected also shows significant differences between the newspapers analysed, differences established through language that led to more often use of the word "inválido" (invalid) by the El Mundo or the fact that the Jornal de Notícias recurrently included references on the matters in sections dedicated to charity and validated the idea that a person with functional diversity 
was a "poor needy". Both Portugal and Spain are countries where the press has not local famous people who were affected by polio and the polio illustration gallery has always been foreign, depriving references and validating invisibility.

However, despite the passage of time, the silence and the imposition of oblivion, polio continued endowed with a great potential to raise fears and be associated with new types of threats, which led to the fact that informative peaks about it were related with events of international scope that could impact on the national one: the artificial creation of the virus and its potential applications for bioterrorism (a vision influenced by the proximity to September $11^{\text {th }} 2001$ ) and the risks of the vaccine due contamination or its composition (presence of mercury, contamination with SV40, prohibited bovine serum due to spongiform encephalitis or the denial of the origin of HIV). Nonetheless, although this traditional discourse on the risks and limitations of science can be a sponsor of Western anti-vaccination, a defence of the achievements predominates. The polio post-vaccine, the development of the virus of the vaccine in the environment and its implications for eradication are not given much attention, in a triumphant discourse in which polio is equated with smallpox, as a paradigm of the power of science in controlling the environment.

Juan Antonio Rodríguez Sánchez is Profesor Titular of History of Science at the Department of Biomedical and Diagnosis Sciences, University of Salamanca (Spain). Inês Guerra Santos is Professor Auxiliar at the Department of Communication Sciences and Information Technologies, Instituto Superior da Maia (Portugal). 


\section{References}

Ballester, Rosa and María Isabel Porras, "La lucha europea contra la presencia epidémica de la poliomielitis: una reflexión histórica," Dynamis 32(2) (2012), 273-285.

Beale, A. John, “The Development of IPV,” pp. 179-187 in Stanley A. Plotkin, ed., History of Vaccine Development. (New York, 2011).

Bouza Álvarez, Carmen, Ana Muñoz van den Eynde y José Ma Amate Blanco, Sindrome post-polio:Revisión de la literatura, situación en España y posibles líneas de actuación. (Madrid 2003).

Entman, R.M., "Framing U.S. coverage of international news: Contrast in narratives of the KAL and Iran air incidents," Journal of Communication 41(4) (1991), 6-27.

Entman, R.M., "Framing: Toward clarification of a fractured paradigm," Journal of Communication 43(4) (1993), 51-58.

European Centre for Disease Prevention and Control. "Risk of introduction and transmission of wild-type poliovirus in EU/EEA countries following events in Israel and Syria - updated risk assessment (9 december 2013). In http://ecdc.europa.eu/en/publications/ layouts/forms/Publication DispForm. aspx?List=4f55ad51-4aed-4d32-b960-af70113dbb90\&ID=983 [15-01-2014]

Gil Prieto, Ruth, "Evolución de los calendarios vacunales en España," pp. 139-156 in Enrique Perdiguero Gil, Enrique and Josep M. Vidal Hernández, coords., Las vacunas: historia y actualidad. (Menorca, 2008).

Guerra Santos, Inês, "A poliomielite em Portugal: o 'Refúgio da Paralisia Infantil'," pp. 177-194 in Dilene Raimundo de Nascimento, org., A história da poliomielite. (Rio de Janeiro, 2010).

Hecht, Alana, Polio. (New York, 2009. 2nd ed.).

Heras Salord, Jaime de, María Isabel Porras Gallo y María José Báguena Cervellera, "El drama de las víctimas de la poliomielitis visto por la prensa, por ellas mismas y sus contemporáneos," pp. 170-192, in María Isabel Porras Gallo, Mariano AyarzaGüena Sanz, Jaime de las Heras Salord y María José Báguena Cervellera, coords., El drama de la polio: un problema social y familiar en la España franquista. (Madrid, 2013)

International Statistical Classification of Diseases and Related Health Problems 10th Revision (ICD-10 Version: 2010), in http://apps.who.int/classifications/ icd10/browse/2010/en [12-07-2012]

Koprowski, Hilary and Stanley Plotkin, "History of Koprowski Vaccine Against Poliomyelitis," pp. 155-166, in Stanley A. Plotkin, ed., History of Vaccine Development. (New York, 2011). 
W. Lippmann, Public Opinion. (New York, 1922).

López Gil, Pablo, Miguel Otero Iglesias, Miguel Pardo Pereira y Miguel Vicente

Mariño, dirs., La imagen del mundo árabe y musulmán en la prensa española. (Sevilla, 2010).

McCombs, Maxwells, Estableciendo la agenda: El impacto de los medios en la opinión pública y en el conocimiento. (Madrid, 2006).

McCombs, Maxwells, A Teoria da Agenda: a mídia e a opiniāo pública. Petrópolis, 2009.

Nascimento, Dilene Raimundo do, Marcos Cueto, Eduardo Ponce Maranhão and Deepak Sobti, "A erradicação da poliomielite na América Latina: comparando Brasil e Peru,", pp. 161-176, in Dilene Raimundo de Nascimento, org., $A$ história da poliomielite (Rio de Janeiro, 2010).

R. Navarro García, dir., Análisis de la sanidad en España a lo largo del siglo XX. Madrid, 2002.

Otero García, Laura, Aproximación a las representaciones sociales sobre la salud de la población inmigrante en el discurso periodístico en prensa escrita española (2000 2006). (Madrid, 2011).

Pinto, Sandrine Martins, Inês Guerra, Juan Antonio Rodríguez-Sánchez, João Rui Pita y Ana Leonor Pereira, "De las campañas de vacunación al calendario vacunal: el Programa Nacional de Vacinação portugués y las Campañas Nacionales de Vacunación Antipoliomielítica en España (1963-1976),”, pp. 203-209, in Ricardo Campos Marín, Ángel González de Pablo, María Isabel Porras Gallo y Luis Montiel, eds, Medicina y poder político. (Madrid, 2014).

Polio Global Eradication Initiative. Plan Estratégico 2010-2012. (Organización Mundial de la Salud, 2010).

Rabeharisoa, Vololona, Michel Callon, Angela Marques Filipe, João Arriscado Nunes, Florence Paterson and Frédéric Vergnaud, "From 'politics of numbers' to 'politics of singularisation': Patients' activism and engagement in research on rare diseases in France and Portugal," BioSocieties, 2014, 1-24, in http://www.palgrave-journals.com/biosoc/journal/v9/n2/pdf/ biosoc20144a.pdf [12-06-2014].

Rodríguez-Sánchez, Juan Antonio, "Responsabilidades não assumidas: a poliomielite na Espanha (1954-1967)," pp. 195-224, in Dilene Raimundo de Nascimento, org., A história da poliomielite. (Rio de Janeiro, 2010).

Rodríguez-Sánchez, Juan Antonio, "La persona enferma como experta: los cambios sociosanitarios promovidos por el asociacionismo polio-postpolio en España," Estudos do Século XX 12 (2012a), 104-122.

Rodríguez-Sánchez, Juan Antonio, "Las secuelas sociales de la polio: los inicios del movimiento asociativo en España (1957-1975)," Dynamis 32(2) (2012b), 391414. 
Rodríguez-Sánchez, Juan Antonio and Jesús Seco Calvo, "Las campañas de vacunación contra la poliomielitis en España en 1963,” Asclepio 61(1) (2009), 81-116.

Rodríguez-Sánchez, Juan Antonio, Rosa Ballester Añón and Inês Guerra Santos, "El movimiento asociativo: una perspectiva internacional, nacional y de los casos de Madrid, Valencia y Castilla - La Mancha," pp. 233-257, in María Isabel Porras Gallo, Mariano AyarzaGüena Sanz, Jaime de las Heras Salord y María José Báguena Cervellera, coords., El drama de la polio: un problema social y familiar en la España franquista. (Madrid, 2013).

Rogers, E. and J. Dearing, "Agenda Setting research: where has it been, where is it going?,” pp. 555-593, in J. Anderson, ed., Communication yearbook II. (Newbury Park, CA, 1988).

Santos, João de Almeida, Media e poder: O poder mediático e a erosão da democracia representativa. (Lisboa, 2012).

Severo, Bruna Meireles, A Imprensa e seus efeitos sobre a audiência. (Rio de Janeiro, 2007).

Seytre, Bernardand Mary Shaffer, The death of a disease: a history of the eradication of poliomielitis. (New Brunswick, 2005).

Smallman-Raynor, Mathew and Andrew D. Cliff, Poliomyelitis: Emergence to Eradication. (Oxford, 2006).

Talley, Colin, "The Combined Efforts of Community and Science: American Culture, Patient Activism, and the Multiple Sclerosis Movement in the United States," pp. 39-70, in Randall M. Packard, Peter J. Brown, Ruth L. Berkelman and Howard Frumkin, eds, Emerging Illnesses and Society: Negotiating the Public Health Agenda. (Baltimore, 2004).

Vigilancia de la Parálisis Flácida Aguda. Informes 2002-2012. Madrid: Centro Nacional de Epidemiología.

\section{Acknowledgements}

This work has been carried out within Project HAR2012-39655-C04-03 of the Spanish Ministry of Innovation, Economy and Competitiveness (MINECO) and SA359A12-1 (Junta de Castilla y León). 